\title{
SUSTAINABLE DEVELOPMENT \\ From Millennium 2015 to Sustainable Development Goals 2030
}

\section{Ergul Haliscelik}

\author{
Mehmet Ali Soytas
}

\begin{abstract}
In modern economies, the advancement of well-being of the citizens should be in an inclusive and sustainable way. In this respect, the sustainable welfare targets should exclusively include 3 main pillars; economic growth, social inclusion and environmental protection. These pillars consist of qualitative and non-monetary, as well as monetary and quantitative indicators to monitor. Although sustainable development today is well-appreciated in most governments' agenda, yet it is generally not a trivial task to measure its progress especially due to multidimensional nature of some targets. In this article, sustainable development is measured by using a wide range of indicators within multi-dimensional perspective of Millennium Development Goals (MDGs) 2015. Indicators cover wide spectrum of areas such as poverty reduction, health, education, gender equality and environment. An index creation method is developed for measuring the level and the performance of countries' progress through achieving MDGs. The index score levels and the rankings of countries are compared to similar indexes developed by UN. Finally, countries are classified according to their achievements relative to other countries (which is measured by the index) versus their self-achievement performances (in terms of improvement of the index over years) in a big matrix. Results demonstrate the importance of measuring country performances in both dimensions. Understanding the progress in MDGs can help settle on binding targets for achieving the country specific goals in economic and non-economic areas and on the mechanisms to implement the Sustainable Development Goals (SDGs) of the 2030 which set amid on the success of MDGs.
\end{abstract}

Keywords: Sustainable Development, Millennium Development Goals, Quality of Life, Poverty, Human Development Index, Emerging Markets 


\section{INTRODUCTION}

Governments can have different priorities in different periods, yet raising the welfare and increasing the quality of life of their citizens often remain at the high ranks of these priorities. To demonstrate credibility, modern governments are expected to relate their development policies to the society with a sustainable system as such the well-being of the citizens should be targeted in an inclusive and sustainable way (Xue et al. 2018). This translates as that economic development should not only promise a high level of income but should also demonstrate itself through better education, health, justice, environment and other socioeconomic indicators (Ramos et al. 2018). In many developed countries economic growth while bringing economic prosperity also created a bunch of new problems in the dimensions related to the former list of indicators (Fox, 2012). In the heart of the problems lies the (un)equal access of the citizens to the resources due to the uneven distrunution of income across the society (Birdsall 2005). Therefore, one can argue that economic growth cannot be entitled as success unless it comes with remedies to reduce poverty, to make income distribution fairer and to create jobs.

Sustainable development is defined as meeting the needs of the present generation without compromising the ability of future generations to meet their own needs. Economic growth, social inclusion and environmental protection are three main different pillars of sustainable development (Wichaisri and Sopadang 2018). Although no dispute arises on the importance of these three dimensions; the progress/achievements of these pillars are not easy to measure in an undisputable way (Banister et al. 2015). In this paper, sustainable development is measured by using both monetary and non-monetary indicators within multi-dimensional perspective of UN Millennium Development Goals (MDGs) of 2015. We collected data from different sources to create measures for the indicators assembled for the MDGs. MDGs cover 8 goals, 21 targets and 60 indicators related to a wide spectrum of issues such as poverty reduction, health, education, gender equality and environment. In this respect they are widely accepted as the most broadly defined development and poverty indicators at both global and country level (Reddy and Heuty 2006).

The paper further creates measures (indicators) at the target and goal levels constructed from the aforementioned indicators proclaimed by MDGs. Our aim is to use higher order indiceslindicators to compare and rank countries using all the available information assembled within the definitions of MDGs. At United Nations Headquarters in New York, world leaders adopted the Millennium Declaration in September 2000. They committed their nations to a new 
international partnership to reduce extreme poverty with a series of time-bound targets with the final deadline of 2015. Following the meeting, the MDGs came into the world agenda with the following explicit goals: end poverty and hunger, make universal education accessible to everyone, maintain gender equality, improve child and maternal health, combat HIV/AIDS, work through environmental sustainability and global partnership. These goals indisputably are providing worldwide reference and therefore presenting an opportunity for international country progress assessments for decision making in critical matters including but not limited to the borrowers and international funding organizations to assess the country performances (Kurniawan and Managi 2017). Table 1 summarizes the MDGs in terms of number of targets and indicators they are related to (McGillivray 2008; Haliscelik 2009).

[ Table 1 here]

A new multi-dimensional Millennium Development Goals Index is constructed from the convolution of 8 goals using the 44 indicators of the aforementioned 60 (that covers 19 targets of the 21 , see Table 1 for details) for 187 countries for the period of 1990-2015 ${ }^{1}$. This index is a summary measure that enables us to compare countries within their progress through the sustainable development goals, yet it is much less daunting than doing the same for each of the goals separately which can be intractable. Still the sub-indices for all goals are constructed, in fact their indicator form versions are used for the construction of this main index. Our method and the final index is in the same lines with many major indexes available including Human Development Index (HDI) of United Nations, therefore we compare our results with it for robustness given its widely accepted position in the literature (Bilbao-Ubillos 2015). New multi-dimensional indices were intended to make a profound transformation of the foundations that builds the sustainable development agenda. The initial focus was unsurprisingly on economic development. Although economic development aspect is essential, it only supports one dimension of country progress and it is meaningful if it contributes to the larger agenda of world economies' transformation to sustainable and inclusive environments (Quental et al. 2011).

\footnotetext{
${ }^{1}$ Given the data limitations, we ended up with 44 indicators for which the analysis can be conducted meaningfully. For other indicators either the time series length or cross country compatibility made us decide to exclude the indicator from the analysis.
} 
Our results show that the index score levels and the rankings of countries are comparable to the similar indexes developed by the UN. We classified countries according to their achievements relative to other countries (which is measured by the index) versus their self-achievement performances (in terms of improvement of the index over years for a country) in a big matrix to demonstrate the progress in these two dimensions. Results demonstrate the importance of measuring country performances in both dimensions. Understanding the progress in MDGs can help settle on binding targets for achieving the country specific goals in economic and noneconomic areas and on the mechanisms to implement the Sustainable Development Goals (SDGs) of the 2030 which set amid on the success of MDGs. The SDGs build on the success of MDGs and aim to go further. Although, MDGs were intended for action in developing countries only, the new SDGs are universal and apply to all countries. SDGs of 2030 cover 17 goals and related 169 targets, 244 measurable indicators and have more a comprehensive list of development goals through 2030 (Spangenberg 2004). Lessons learned from MDGs can be important for better measuring and assessing the progress of SDGs of 2030. Better measurement is of immense importance to many stakeholders and would be much appreciated particularly by international funding organizations and policy makers of the beneficiary countries to implement selective policies to use funds more effectively (Allen et al. 2017).

The paper is organized as follows. Next section presents the existing indexes in the literature and compare them with the current index constructed. Data and method is discussed in the following section. Country comparisons and tabulations are presented in the next section. The final two sections display the extensions of the index by combining monetary and nonmonetary measures and the conclusion and policy recommendations consequently. Some of the larger tables and maps are provided in the Appendix of the paper.

\section{MULTIDIMENSIONAL POVERTY INDEXES}

Poverty is a global phenomenon. Today we even talk about poverty in developed countries which was almost unimaginable two decades ago when poverty was mainly associated with basic material needs for survival (IFAD 2010). This on the other hand underlines the relative nature of the poverty definition as such we almost surely mean different aspects of the same definition when we talk about poverty in the Sub-Saharan Africa versus for instance in the U.S.A. Nonetheless, it is a relative term and can vary depending on one's monetary and nonmonetary living conditions, as well as society's development level and environmental 
conditions.

There are different approaches available for measuring poverty, but what common in all these approaches is the methodology that it is measured in several steps. First step generally is the determination of a poverty line in order to differentiate the poor from the non-poor. However, determination of the poverty line itself depends on how we define poverty (Bradshaw, 2001). Therefore, various assumptions bring multiple measures of poverty line and consequently multiple measures of poverty. Therefore, there is no consensus on a single poverty line, but instead a variety of definitions prevail. Upon determination of the poverty line, poverty measure is generally constructed as an index. Earlier approaches for constructing the index mailny focused just on the economic welfare and this sort of calculation still has remained the most widely used methodology. This does not necessarily reflect the superiority of this measure, but the reason for its long dominance is related to the vast availability of economic data for calculating poverty along this dimension (Bartolj et al. 2018). Most commonly used method to measure economic welfare is through using household consumption expenditure or household income. Those are often calculated from household surveys and they form the base data for measurement of poverty (Haughton and Khandker 2009)

Table 2 summarizes the commonly used poverty indices. For each index in the table, existence of the dimensions related to education, health, knowledge, decent standard of living, social exclusion beside income (traditional standard of living) are reported. If an index acknowledges addressing any of these dimensions, the number of indicators used to identify this dimension is reported in the subsequent colum. For instance, Human Development Index (HDI) addresses health and does it using one indicator, whereas it addresses education with 2 indicators. Contrasted with Table 1 from which we use MDGs indicator definitions for our index construction, we consider 44 indicators, 19 targets and 8 goals $^{2}$ in total to construct our poverty/sustainability index. Clearly it is more dimensional than any of the indexes in Table 2, and hence has the potential to convey better information about the country development performances.

[ Table 2 here]

\footnotetext{
${ }^{2}$ See Footnote 1.
} 


\subsection{Multidimensional Poverty Indexes Developed by UNDP}

As seen in the Table 2, poverty is mainly measured based on the income level. However, considering just income or consumption data might not be enough to measure poverty. Some socio-economic indicators, particularly education and health, can be used to better measure poverty beyond income. Therefore, multi-dimensional poverty indexes are based not only on monetary (income, consumption, expenditure) but also non-monetary indicators (Senses, 2003) for this purpose.

While stressing the impact of income on development, the UNDP has created a variety of multidimensional composite indexes since 1990 by taking into consideration the idea that economic growth does not always lead to human development. Many non-monetary indicators such as infant mortality rates, life expectancy at birth, literacy rate, gender equality, the enrollment rate, and access to clean drinking water and public goods, unemployment rate are used to calculate multi-dimensional poverty-development indexes. Then, the development levels and performance of the counties are measured and compared accordingly.

In this regard, Human Development Index (HDI) is the first development index developed by the UNDP in 1990. Following that, Human Poverty Index (HPI) was developed in 1997 with the idea that HDI was not covering enough the poorest part of the society. Then, the Gender Development Index (GDI) was developed by using life expectancy, education and income, also some other indicators used in the HDI. The GDI is separately calculated for men and women and it is designed to measure the gender equality. Later, the Multidimensional Poverty Index (MPI) was developed in 2010 by using 3 dimensions (education, health and living standards) and 10 related indicators to replace the previous GDI. Finally, the Gender Inequality Index (GII) is developed for measurement of gender disparity. GII is a composite measure of the loss of achievement within a country due to gender inequality by using 3 dimensions (reproductive health, empowerment, and labor market participation) and 5 related indicators. These indexes should not be seen as substitutes for each other, but rather as they have comparative strengths in different aspects of the development so can be seen as complements to each other. UNDP has measured and shared the results of the countries' performances on transforming their economic growth to human development by using these indexes (UNDP 2009), (UNDP 2010), (UNDP 2011), (UNDP 2012), (UNDP 2013), (UNDP 2014).

All but the Global Gender Gap Index (GGGI), shown in the Table 3 are developed by the UNDP. GGGI is rather developed by the World Economic Forum in 2006 to measure gender 
equality and increase awareness at global and country level for gender based discrepancies in outcomes. GGGI benchmarks national gender gaps and ranks countries and regions according to how well they are leveraging their female talent pool, based on "Economic participation and opportunity", "Educational attainment", "Political empowerment" and "Health and survival" indicators. GGGI is composed of 4 dimensions with 13 indicators using weighted average method for the calculation of final index. It is an effective comparison across regions and income groups. GGGI is widely used by NGOs, researchers, media organizations, markets, governments, international organizations and individuals for various purposes. The methodology in GGCI has some similarities with that of MDGs index (World Economic Forum, 2014).

The HDI has been developed by the United Nations as a metric to assess the social and economic development levels of countries. It is a composite statistic with 3 dimensions: A long and healthy life (measured by life expectancy at birth), education (measured by mean years of schooling and expected years of schooling) and a decent standard of living (measured by GNI per capita, PPP US\$). HDI with 3 dimension and related 4 indicators is used to rank countries into four tiers of human development. The computed HDI of a country is a geometric mean of normalized indexes of each of the sub-indexes related with each dimension. The dimensions and related indicators of HDI and all other related indexes are summarized in Table 3.

[ Table 3 here]

In this paper, while benefiting from the methodologies of indexes mentioned above, the dimensions of sustainable development will be measured by using both the monetary and nonmonetary indicators within a multi-dimensional perspective of MDGs of 2015.

\section{DATA AND METHOD}

\subsection{Data and the Fundamentals of the Method}

This section develops our method for creating the MDGs index. The very first step of our analysis is finding the right proxies for the indicators of MDGs. We searched various databases to construct the indicators for this purpose. Data for indicators are obtained from various 
databases of different international organizations, however we benefited particularly from the World Bank database extensively ${ }^{3}$.

World Development Indicators (WDI) provide current and accurate development data at both national and international levels. These data which have been approved by the UN and member states, the World Bank and partner organizations, allow us to monitor progress in countries, in regions and at globe on MDGs. WDI cover more than 150 economies, 14 groups of countries and 800 indicators, and thematically includes world view, people, environment, countries, markets and global connections. The World Development Indicators CD-ROM includes time series data for more than 1000 development indicators covering the period 1960 to 2013 for the 216 economies. (World Bank 2014/a).

World Bank MDG Online Data Set is a revised version of the World Development Indicators data set in line with the MDG objectives and objectives. The data set is updated four times a year in April, July, September and December respectively. The data covers 134 indicators, including the indicators of the MDGs covering the period of 1990-2013 of the 214 countries from which we created our 44 indicators in this paper. In the analysis, we used a data set from 1990 to 2015. Therefore, we extended the time series from from this source using data from relevant international organizations, which are used in the creation of the World Bank development indicators ${ }^{4}$. We constructed the indexes for the same 187 countries which also covered by the HDI. This creates a possibility to check our results in comparison to the calculations from HDI.

Index values are constrained to be between 0 and 1 . This is basically a normalization to allow for cross index comparisions as well as comparisons within the same index across countries. To normalize in terms of the positive or negative meaning of the underlying indicator, i.e. a higher literacy rate is a better, however a higher child mortality is a worse outcome, we constructed the index value higher for the better outcome of the specific indicator. Missing values are always a big problem in studies dealing with multiple year, multiple country datasets, and our study is not an exception. We analyzed our indicators therefore, to decide on the optimal time series length after correcting for the missing data issues. Finally, upon constructing the 1990-2015 dataset for 44 (out of 60) indicators consistently for 187 countries, we constructed

\footnotetext{
${ }^{3}$ World Development Indicators Online, CD-ROM and Book, Millennium Development Goals Online 2014.

${ }^{4}$ The data sources and the respective international organizations that are refered for completing the data set to 2015 are provided in Appendix 6. We futher supplied the links to the relevant datasets in the Appendix Table for interested reader.
} 
target level indicatorslindices ${ }^{5}$ using the weighted average of the indicators that are defined for the corresponding target.

The weighted average chosen as the method to proceed. This needs some explanation. In the literature, generally arithmetic, geometric and weighted averages are used in index calculations. Depending on the averaging method used, significant differences may occur in the index values. We started by creating independent indices for each of the 44 indicators that could be included primarily in the calculation of the MDGs General Index. In the next step, by using the average of the relevant indicators, the indexes of the 19 targets; and then the averages of the indexes for the 8 MDGs by taking into account the averages of the targets, and finally, the MDG General Index was formed. The MDG index and success levels were calculated separately with arithmetic, geometric and weighted averages and the results were compared.

In the calculations using arithmetic average, high success in one indicator compensates for the low success level in another indicator. Since the standard deviation value was not taken into account, the index and success levels were found higher than the geometric average results. In addition, since the indicators used in the calculation of the index are given equal weight by construction, this caused one-to-one substitution of the indicators even though the precision of the information possibly had been different. When geometric average was used in the calculations, this substitution effect is naturally decreased by implicit inclusion of the standard deviation of the indicator values used in the calculation. The difference between the two index values increases as the value of standard deviation increases for the indicator values used, and the increase is in favor of the arithmetic mean method. This can be particularly problematic when large number of incidicators are used for index construction since with geometric average low indicator values gets lower weight while high indicaor values gets higher weights on average, and hence a superior performance in one indicator and/or in one sub-index can cause a large deviation in the country's overall ranking. This is a well-known problem with the construction of index functions.

In the calculations made by using the weighted average method, the above mentioned disadvantages in arithmetic and geometric mean methods have been tried to be eliminated. In this context, standard devaiation is explicitly taken into consideration and the weights are

\footnotetext{
${ }^{5}$ At the target level and at higher levels, the indicators and indices are basically referring to the same thing. For instance, the constructed target level indicators are weighted average of the indicators which are normalized for the respective target. From a method point of view, the target level indices are then used as indicators for constructing the goal level indices, and so on. Therefore, apart from the initial 44 indicators, the indicators and sub-indices refer to the same constructed measure.
} 
calculated by taking the inverse of respective standard devaitions of the indicators. This method aims to favor more preceise information (lower standard deviation) in expense of less preceise one (higher standard deviation) ${ }^{6}$.

In Table 1, we report the aggregate number of indicators for the total targets defined for a particular goal ${ }^{7}$. These target level indicators constructed this way are actually themselves subindexes, and cross country comparison along those targets can be conducted at this stage. However, though this can be an interesting research exercise, it is not the main focus of this paper and we leave it for possible future research. We further proceed to construct the goal level indiceslindicators using the constructed target indicators. 8 goal level MDG indicators were calculated by taking the weighted averages of the relevant target indicators. Again we have plenty of sub-indices created at this stage at the goal level which can be of interest to be compared across countries. Finally, by taking the weighted average of these 8 goal level indicators, a general index of MDGs and subsequently from it, a MDG General Performance level index is constructed. These last wo indices are the main focus and they are used for cross country comparisons in the rest of the paper.

The stages of our index construction method are shown in Figure 1 using MDG 1: "eradicate extreme poverty and hunger" as an example. The other MDGs follow similarly. The summary of stages is further described in the Appendix.

[ Figure 1 here]

The method we used to construct the MDG index and the subsequent MDG performance index falls in the same line of approaches used by other researchers/institutions previously. The followsaforementioned index by UN for instance follows a similar methodology, yet details such as the weighting scheme applied to the indicators are slightly different. However, our

\footnotetext{
${ }^{6}$ The comparison of the results with arithmetic, geometric and weighted averages would increase the already populated list of tables and figures, yet we believe is not critical in terms of the main contribution of the paper. One can think of it as such the method for creating our multidimentional MDG index depends on the weighting scheme we use for constructing the sub-indexes. This is true for our method, yet it is true for any index calculation methodology. However, results for the other averaging methods can be supplied upon request.

${ }^{7}$ We do not report the specific names and number of related indicators of each target for brevity. For more detailed information on the targets and their corresponding indicators, we refer the interested reader to UN, 2012/a, Official list of MDG indicators.
} 
method's main difference and consequently main contribution is that a MDGs index is created by considering the average of 44 indicators, 19 targets and 8 goals applied to 187 countries for the period of 1990 to 2015 . In this respect it is up to our knowledge one of the most comprehensive multi-dimensional development indexes in the current literature. We believe this alternative index can trigger further research initiatives such as comparing countries in the sub-index categories, developing combined indexes from sub-indexes of various combinations.

\subsection{Calculating MDGs Index and Measuring Development Level of the Countries}

As stated, the purpose of developing the current index is to compare and rank countries with respect to their multidimensional development goals in a consistent way. The development levels of the 187 countries considered in this paper are therefore, will be evaluated according to the constructed MDG Index. The index is created as such the values are constrained to be between 0 and 1 . We followed a simple normalization by taking into account the range of possible values of the underlying final indicator. This normalization is considered for a better cross index comparison as well as comparisons within the same index across countries. The maximum and minimum values of the corresponding indicators in the sample are used to constraint the index between 0 and 1 .

The index value is calculated as the ratio of the difference from the minimum to the difference between maximum and minimum for that particular indicator if the higher values of the indicator mean a better outcome. The procedure is changed slight as such the index value is obtained as the ratio of the absolute value of the difference from the maximum to the difference between maximum and minimum for that particular indicator if the higher values of the indicator indicates a worse outcome (such as under-5 mortality rate).

After obtaining the index values, we further rank countries in terms of a discrete scale which labels the development stages of their economies with respect to reaching the sustainable development goals. In this respect, we developed five discrete scales ranging from very low development to very high development (1-very high development, 2-high development, 3medium development, 4-low development, 5- very low development). The grouping of the countries within each label is determined as follows. As the maximum index value is 1.00 , the development level of the country having at least an index value below 0.2 standard deviation 
from maximum value is determined as "very high" index values for this group are between one standard deviation and 0.2 standard deviation. The "medium" group lies between one and two standard deviations interval. The "low" development group of countries are determined as such their index values are between two and three standard deviations. Finally, the "very low" group is between three standard deviations and the minimum index value in the sample. Countries are ranked according to the development index level in these five categories. Table 4 displays the method and the cut-off points of the development level of the countries for the "net primary enrolment ratio" indicator as an example. Same method was applied for all the indicators, targets and goals of MDGs.

\section{[ Table 4 here]}

General MDGs Index is calculated by taking the weighted average of the 8 goal level subindices. Table 5 presents some of the key statistics used in the calculation of the weights and finally in the last column the weight of every MDG in the calculation of General MDGs Index. Therefore, the final MDGs Index is obtained as a weighted average where the weights are inversely related to the standard deviation of the respective MDGs index. A goal or indicator with a small variability or standard deviation then gets a larger weight within the sub-indexes or similarly within general index.

[ Table 5 here]

\subsection{Measuring MDGs Success (Performance) Level of the Countries}

Our data set covers years from 1990 to 2015. What had unfolded between 1990 and 2015 can be one of the important and most significant remaking of the structure of the development of

\footnotetext{
${ }^{8}$ We applied different criteria at this stage for deciding the cut-off points for each interval that leads to the grouping from low to high. The one presented in the paper mimics the criteria UN follows and the ranking of the countries are therefore at this highest level of aggregation resembles that of UN. However, we should also note that given the 44 indicators used, rankings in the sub-indices can be quite different for countries under consideration from the main index and this, we find important for better understanding the country progress. Our method in this respect provides a unique opportunity with a comprehensive index to explore along those dimensions.
} 
countries since MDGs came to the world agenda. In this section, we perform an exercise as such the level of success or the performance of the countries on achieving the MDGs becomes the question of interest. Therefore, different from the previous section where the general MDGs Index had produced the formula that came to be used for comparing countries, the performance level measurement of a country acknowledges us with a comparison along the same country over years. Hence, the analysis provides a solution to the monitoring of the progress in the MDGs for a particular county. This, we find important. Every country has a unique structure. Although it operates generally as one economy with a central government, as far as the multidimensional development goals are considered it is actually owned by many separate stakeholders and decision makers. Therefore, progress in different dimensions can be the compromise reached to carry out a much bigger agenda and hence achievements can be quite different along different dimensions. The performance level of countries is therefore measured by comparing the values of the related indicators, targets and goals between the base year (1990) and the target year (2015).

As the maximum rate is defined naturally as $100 \%$, countries' success level is measured according to the projected levels in 2015 with the following formula:

Estimated Performance Level of a Country in target Year (2015) comparing with base year (1990)

(MDGEstimadedValue2015-MDG BaseYearValue1990) / MDG $_{\text {BaseYearValue1990 }}$

Measurement of Performance Level of a Country in target Year (2015) (\%)

Success/Performance Level (\%) = Min (MDG EstimatedPerformancelevel $/$ MDG TargetedPerformancelevel, \%100)

Similar to the calculation for the index levels, we developed five discrete scales ranging from unsuccessful to very successful (1-very successful, 2-successful, 3-partially successful, 4partially unsuccessful and 5- unsuccessful). As the maximum success is defined as $100 \%$, the success level of the country having at least 0.2 standard deviation below of maximum value is determined as "very successful" . The method for constructing the other intervals for the

\footnotetext{
${ }^{9} \mathrm{We}$ applied different crtiteria at this stage for deciding the cut-off points for each interval that leads to the grouping from very successful to unsuccessful. The one presented in the paper mimics the development rankings by UN and at this highest level of aggregation are targeted to be consistent across the two metrics developed in the paper. Given the 44 indicators used, rankings in the sub-indexes can be quite different for countries under consideration from the main index and this we find important for better understanding the country progress.
} 
successful, partially successful, partially unsuccessful and unsuccessful applies the same decision rules regarding the respective standard deviations as for the general index case. Countries are then placed according to their success levels within these discrete outcomes. Table 6 displays the method and the cut-off points of this method again using the "net primary enrolment ratio" as an example.

With this later comparison, countries achieving their goals or performing better than the announced targets are evaluated as "very successful". This method has been also applied for all indicators, targets and goals of MDG and success/performance level of the countries are calculated separately for all.

[ Table 6 here]

MDG General Performance/Success level is calculated by taking the weighted average of the 8 goal level success measures. Table 7 describes the key statistics used in the calculation and final weights of every MDGs in the general success level of the countries. As before, final MDGs success level is measured by the weighted average method by taking into consideration the standard deviation of each MDGs.

[ Table 7 here]

\section{COUNTRY COMPARISIONS}

\subsection{Development Levels of the Countries}

Table 8 summarizes our index and related rankings associated with it for a select group of countries. As seen in the top row of the table, Sweden is in the first place with an index value of 0.9764 and associated development category of "very high". Germany, Netherlands, Norway and Switzerland follow Sweden. When we compare the emerging economies of G20, South Korea and Mexico have the highest index values. Their ranks are 32nd and 47th respectively. Turkey, another relatively big emerging economy having an index value of 0.8419 finds its place in the "medium" development level and it is ranked 97th among 187 countries. 
[ Table 8 here]

An immediate observation emerges such that index values vary according to the region (See Figure 2). MDGs index values are higher in the European Union, Europe and Central Asia, where per capita incomes are also higher than those of other regions. On the other hand, South Asia and Sub-Saharan Africa regions typically having lower incomes per capita have also lower index values than those of other regions.

[ Figure 2 here]

In other words, not surprisingly there is a high positive correlation between per capita incomes and development levels of the countries. Indeed, based on the rankings from our index, Chad is in the last row of the list with an index value of 0.5441. Central African Republic (0.5619), Sierra Leone (0.5841), Democratic Republic of Congo (0.5990) and Liberia (0.6050) follow Chad at the bottom of the list. The same result can be seen from the development levels of these countries in the fourth column in Table 8 in which these countries located in Africa have "very low" development levels. Rest of the columns in the table present the rankings of the countries with respect to the eight goal level indices. There is more variation across the rankings at the goal level and some interesting patterns emerge. Indonesia for instance although classified as "medium" in the general development level, finds a place in the "high" category for the MDG 2 related to education. Similarly, Turkey is in the "medium" group in the overall level, yet grouped as "very high" regarding education and "high" regarding child and maternal health. Certainly none of the development indices of the world's major institutions neither ours would ever achieve to summarize all the dimensions of development with a single index, therefore there remains much valuable information along the sub-index categories. This, particularly makes our index valuable as such we expect that the disparity of these sub-indexes could trigger a better understanding of the evolution of the development process as well as country specific contingencies.

We further present in Figure 3 and Figure 4 that there are significant differences among the 
income groups in their MDGs index values that persist over periods. Figure 3 shows the progress in the index values of the countries in different income groups over the period from 1990 to 2015 using World Bank income level classification. The most dramatic change of all groups is in low income countries. Their index values start as very low in 1990, and improves the most. Lower-middle countries demonstrate a similar pattern. Though being low compared to higher income countries, their index values are much higher than the low income counties. For these groups, from 1990 to 2000, and then from 2000 to 2010, index values improve considerably. This sharp increase is most likely to be related to the already low (if not lack of) starting resources in the dimensions that are evaluated in the sustainable development indices. For countries that are upper-middle or higher, index values improve modestly. In comparison across income groups, there emerges a pegging order in terms of income of the country where in any year, the average index value for a particular income group counties are larger than the preceding income group countries.

Figure 4 makes the compassion across income groups for the year 2015 using the eight goal sub-indices. From this comparison, we can infer that there is more variation across goals, and income matters more in some goals more than others. However, also a clear pattern emerges as such upper-middle and higher income counties mostly perform close to each other while low and lower-middle countries clearly are separated. An immediate policy action would be to contemplate a separate and possibly a more intense sustainable development agenda for achieving certain targets in these later group of countries.

\section{[ Figure 3 here]}

From the 187 countries sin our sample we calculated the average value of World MDGs index. In our method, the corresponding number is 0.8076 and the development level is "medium". To get some perspective, we also calculated averages of the World Bank income classifications of countries. According to this later calculations, low-income countries has an average MDG index value of 0.6795 and their development level is "low". Middle income countries has an average MDG index value of 0.8033 and their development level is obtained as "medium" and finally high income countries" average MDG index value is 0.9287 , and their development level is "high". According to these results, our method not surprisingly verifies the main characteristics of country facts in the development. Also the time series patterns confirm that for all income 
groups, index values increase over time (Figure 3). It is worth noting that the positive correlation between the per capita income and the MDG index scores are captured as mentioned before (Figure 4).

[ Figure 4 here]

\subsection{Success and Performance Levels of the Countries}

Table 9 presents the results of MDGs general success level, rank and success level of the countries for the main aggregate as well as for each goal level. As seen in the table, according to the estimated level of achievement (performance) in 2015, Sweden takes the first place by achieving $89.27 \%$ of the MDGs on average. Its success/performance level is assigned as "very successful" according to our method. Singapore, Norway, Poland and Ireland follow Sweden in the list. When we compare the emerging economies of G20, China (16th) and South Korea (29th) have the best performances. Turkey on average achieves $79.50 \%$ of the MDGs, has an index value of 0.8419 which corresponds to the "partially successful" performance level. Furthermore, Turkey is ranked 88th among 187 countries. The strong positive association between success levels (performance) and per capita income of countries is not as clear as the case between their development levels and their per capita income. Results vary depending on the countries considered. Still, however high income OECD countries are the most successful, and low income countries are in the least successful group.

[ Table 9 here]

Success rates are higher in the European Union, Europe and Central Asia, where per capita incomes are also higher. Similar to the development levels, South Asia and Sub-Saharan Africa regions with relatively lower per capita income have lower General MDGs success level than other regions. Based on the success ranking, Chad with a 59.70\% success level is on the bottom of the list. Central African Republic, Ivory Coast, Nigeria and Sierra Leone comes after Chad respectively. According to our results, the aforementioned countries located in Africa have the "unsuccessful" performance level (Figure 5). Similar to Table 8, rest of the columns in Table 9 
present the rankings of the countries with respect to the eight goal level achievements. We can immediately see that there is a lot of variation across the rankings at the goal level within a given general success level.

[ Figure 5 here]

As shown in Figure 5 and Figure 6, there are significant differences between the regions and income groups. However, contrasted with Figure 2 and Figure 4, these differences are somewhat less subtle. For instance, success levels of some of the goals in Sub-Saharan Africa region are comparable to others regions. Moreover, in Figure 6, we can observe better outcomes for upper-middle income countries than high income OECD and high income non-OECD countries.

[ Figure 6 here]

World MDGs average success rate is calculated as $\% 76.17$ and its performance level is determined as "partially successful" with our method. Based on the World Bank income classifications, low-income countries' MDG average success rate is calculated as 72.93 and the corresponding performance level is assigned as "partially unsuccessful". Middle income Countries' MDG average success rate is obtained as 77.52 and their performance level with our method is assigned as "partially successful". Finally, MDG average success rate of high income countries are calculated as 83.68 , while their performance level is considered as "successful" (Figure 6).

\subsection{Comparing the Results of the Development (Index) and Success (Performance) Levels of the Countries}

A matrix is created to compare the results of the development (index) and success (performance) levels of the countries. Figure 7 presents a matrix of 187 countries' MDG indexes and success levels. While the horizontal axis of the matrix shows the MDG success 
(performance) level of the countries, the vertical axis presents the MDG index value and development levels, respectively. Matrix consists of 25 (5X5) cells.

While MDG development (index) and success (performance) level index for some countries have similar results, some countries are subject to significant deviations. Only 7 countries (Germany, Australia, France, Sweden, Switzerland, Luxembourg and Norway) have "very high" development levels, while, at the same time, they have "very successful" performance levels on achieving MDGs. The matrix cell represented by "medium" development level and "partially successful" performance level in our method, has the largest number of countries. There are 40 countries in this cell including the big emerging countries such as Turkey and Indonesia.

[Figure 7 here]

\section{EXTENSIONS}

\subsection{Extended MDGs Index}

A goal or index with a small variability or in other words with a small standard deviation gets a larger weight within the sub-indexes or similarly within the general index. MDG index does not include the per capita income, which is obviously considered as an important ingredient of countries' development levels. To address this deficiency, an extended MDGs index is created by using the weighted average of the income index (which we refer also as a monetary indicator) and our MDG Index (consisting of non-monetary indicators already developed in the previous sections).

\section{[ Figure 8 here]}

Figure 8 presents a matrix of the 187 countries' MDG and Income indexes. While the horizontal axis of the matrix shows the Income index (calculated according to 2013 per capita GDP in PPP), the vertical axis shows the MDG index value and development levels of the countries, respectively. Matrix consists of 25 (5X5) cells. As shown in the figure, while MDG development index and Income level index for some countries have similar results, some 
countries are subject to the significant deviations. Only 12 countries (Germany, Australia, Belgium, Denmark, France, the Netherlands, Sweden, Switzerland, Iceland, Canada, Luxembourg and Norway have "very high" development levels, while, at the same time, they are among the countries having "very high" income index values. In other words, these countries have very high development levels in terms of both monetary indicator and nonmonetary indicators (MDGs). The matrix cell represented by "medium" development levels in terms of both monetary and non-monetary indicators, has the largest number of countries that includes big emerging economies of Turkey and Indonesia. In total, there are 44 countries in this cell.

On the other hand, as shown in Table 10, when MDG index results compared with the results of the Extended MDGs (E-MDGs) index, significant differences are found for some countries in terms of their index values, rankings, and their corresponding development levels. The vast majority of poor countries have failed to converge to developed countries in terms of monetary indicator. Possible reasons for this could be the unfair income distribution in many of these countries, though this paper does not bring a causal explanation for this phenomenon. Possibly future research can shed some light on this issue. However, we observe from the table that when the non-monetary index (MDGs) is considered, the gap between these countries has gradually decreased. In other words, the convergence of poor countries to developed countries in terms of non-monetary indicators has been relatively more successful than for the monetary indicator.

\author{
[ Table 10 here]
}

\title{
5.2 SDGs of 2030 and Lessons Learned from MDGs of 2015
}

Following the MDGs of 2015, further processes and goals for achieving sustainable development has been needed in both global and country level immediately. This gap was filled when on 25 September 2015, the 194 countries of the UN General Assembly adopted the Sustainable Development Goals (SDGs), officially known as "Transforming our world: the 2030 Agenda for Sustainable Development”. SDGs is a set of 17 global goals including ending poverty and hunger, improving health and education, achieving gender equality, promoting inclusive and sustainable economic growth, making cities more sustainable, combating climate change, and protecting oceans and forests that scans 169 targets and related 244 indicators.

The roots of this new initiative with a common global vision for an economically, socially and 
environmentally sustainable future for the planet and for present and future generations was addressed at the Rio+20 Conference in June 2012. In this conference, it was agreed to develop universal sustainable development goals (SDGs). UN special event took stock of the efforts made towards achieving the Millennium Development Goals (MDGs) in 2013. The main point was to accelerate progress until 2015 and start exchanging ideas on what could follow after the target year of 2015. There has been still unfinished business of the current MDGs. These gaps accordingly should be completed during the SDGs of 2030 by taking into consideration lesson learned from MDGs. SDGs are fundamental and overarching objective for the continuous improvement of quality of life for current and future generations (European Commission, 2013). To ensure prosperity for all as a part of a new sustainable development climate, 17 Sustainable Development Goals (SDGs) of the 2030 agenda officially came into force with specific targets to be achieved over the following 15 years. The SDGs were built on the success of MDGs and were carefully crafted to go even further to end all forms of poverty and achieve further beyond. In comparison to 8 MDGs with 21 targets and 60 indicators, 17 SDGs comes with 169 targets and therefore are more detailed and broader in scope. Governments have the primary responsibility for follow-up and review at the national, regional and global levels regarding the progress made in implementing the SDGs and targets until deadline of 2030. They are expected to take ownership and establish national frameworks. Table 11 summarizes the SDG goals and associated number of targets and indicators. As seen in the table, 17 SDGs and 169 targets will be monitored and reviewed in the new agenda with 244 global indicators (UN, 2017). This SDG framework already has started to be the global standard to measure development and success level of the countries with respect to sustainable development.

\section{[ Table 11 here]}

We believe that there are certain lessons to be learned from MDGs both conceptually and in terms of measurement issues that can proved to be useful for SDGs. In terms of the later, analyses and methods (starting with collecting raw data, processing the data, calculations and evaluation of the results) created for MDGs may be benefited for measuring development level and the performance of the countries on achieving the SDG targets. In this respect our method in this paper can be a useful input to the process.

Figure 9 describes graphically how our method can be adapted in the SDGs context. First step 
would be to obtain the proxies for the indicators. Following, each of the 244 indicators should be analyzed and then by using the weighted average of these indicators, the related 169 targets should be constructed. So the sub-indexes for the level of success and development of the countries should be created both for indicators and related targets. next 17 goals of SDG should be calculated as averages of the relevant targets. Finally, by taking the weighted average of these 17 goals, a general development level index and similarly a general performance level index for SDGs can be created. Such an index can be used similarly as the index we created for MDGs in this paper, and has a potential to be a policy assessment tool of country development.

[ Figure 9 here]

\section{CONCLUSION AND POLICY RECOMENDATIONS}

International funding organizations, with different missions, scope and priorities and specialization in different aspects of development, should complete each other in coordination and harmonization of their activities by taking into account the priorities of the beneficiary countries. International organizations, taking into account their comparative advantages, should implement necessary policies to achieve today's and future's development goals. If they work together, they can use funds more economically, efficiently and effectively on achieving MDGs, SDGs and other desired development results.

Standard, understandable and measurable development goals should be in the best interest of every stakeholder in the process and especially should be considered as country/region performance indicators by the international funding organizations, which often provide the necessary funds for the projects and programs on achieving targets for both global and countrylevel issues. In addition, beneficiary countries (in fact all countries) should adopt these indicators for the same purpose to increase transparency and also better monitor their progress in achieving sustainable development.

There are still open issues of MDGs which can prove useful in understanding SDGs. These gaps should be filled during the early era of SDGs of 2030 by taking into account the lessons learned from MDGs. SDGs has been built amid the success of MDGs and now are the international benchmark of development, sustainability and continuous improvement of quality 
of life. They are with 17 goals, 169 targets and related 244 indicators are broader in scope than the MDGs. Furthermore, SDGs are broader in targets as such conntinious improvements for rich and middle-income counties are far more strongly emphasized than it was for MDGs. In this respect, data analyses, method and results of our study can be generalized to the SDG context and make contribution on measuring UN Sustainable Development Goals of 2030.

The paper reports the MDGs Index value and MDGs success level of the 187 countries analyzed in our sample. Countries are classified according to their achievements relative to other countries (which is measured by the created index) versus their self achievement performances (in terms of improvement of the index over years for a country) in a big matrix. Findings suggest the importance of measuring country performances in both dimensions. General MDGs Index produces a method that can be used for comparing countries, the performance level measurement on the other hand acknowledges us with a comparison along the same country over years. Hence, our analysis provides a method for monitoring the progress for a particular county by both comparing it with respect to other counties and within itlself. We provide this distinction across all the MDG goals separetly since progress in different dimensions can be a compromise of a much biger agenda and hence achievements can be quaite different along different dimensions. Finaly, the analysis can contribute to the implementation of selective policies since the method presented in the paper allows the countries to be ranked according to well defined objective success rankings based on indicators from objective data. 


\section{REFERENCES}

Acemoglu, D. and Robinson, J. (2012), "Why Nations Fail: Origins of Power, Poverty and Prosperity”, Crown Publishers, New York, March 2012, Pg:1-529.

Allen C., G. Metternicht and T. Wiedmann (2017), "An Iterative Framework for National Scenario Modelling for the Sustainable Development Goals (SDGs)", Sustainable Development, September/October 2017, Volume 25, Issue 5, Pg:372-385.

Banister D., N. Schoenaker, R. Hoekstra, J. P. Smits (2015), "Comparison of Measurement Systems for Sustainable Development at the National Level" Sustainable Development, September/October 2015, Volume 23, Issue 5, Pg:285-300.

Bartolj T., N. Murovec, R. Slabe-Erker (2018), "Development of a Household Sustainable Consumption Index and Its Application to EU-28" Sustainable Development, January/February 2018, Volume 26, Issue 1, Pg:34-50.

Bilbao-Ubillos J. (2013), "The Limits of Human Development Index: The Complementary Role of Economic and Social Cohesion, Development Strategies and Sustainability", Sustainable Development, November/December 2013, Volume 21, Issue 6, Pg:400-412.

Birdsall, N. (2005). "The World is Not Flat: Inequality and Injustice in our Global Economy". UNU World Institute for Development Economics Research (UNU-WIDER). WIDER Annual Lecture 9.

Bradshaw, J. (2001), “Methodologies to Measure Poverty: More Than One Is Best!", Paper for International Symposium Poverty: Concepts and Methodologies Mexico City March 28/29 2001, Pg:1-13.

Brunori, P., F.Ferreira, M.Lugo and V. Peragine (2012), "Opportunity sensitive Poverty Measurement", Second World Bank Conference on Equity, Washington-June 27th and 28th, 2012.

Cingano, F. (2014), “Trends in Income Inequality and its Impact on Economic Growth”, OECD Social, Employment and Migration Working Papers No. 163, OECD Publishing, France, 2014, Pg:129.

Çilingirtürk, A.M. and D. Altaş (2010), "Makro İktisat Verilerinde Kayıp Verilerin Regresyona Dayalı En Yakın Komşu "Hot Deck” yöntemi İle Tamamlanması”, Dokuz Eylül Üniversitesi İ.İ.B.F Dergisi, Cilt:25, Say1:2, Year:2010, Pg.73-83.

European Commission, (2013), “A Decent Life For All: Ending Poverty and Giving the World a Sustainable Future", Communication From The Commission To The European Parliament, The Council, The European Economic And Social Committee And The Committee of the Regions", Brussels, 27.2.2013 Pg:1-21.

Filho, S.A., (2010), "From Washington Consensus to Inclusive Growth: The Continuing Relevance of Pro-Poor Policy Alternatives", Department of Development Studies SOAS, University of London, Background paper World Economic and Social Survey 2010, 4 JAN 2010, Pg:1-58

Fox, J. (2012), "The Economics of Well-Being", Harvard Business Review, From the JanuaryFebruary 2012 Issue, https://hbr.org/2012/01/the-economics-of-well-being [Retrieved, 30.12.2016].

Haliscelik, E. (2009), "Cooperation of the International Funding Organizations for Developing Countries - The Case of Turkey”, Carnegie Mellon University Heinz College, May 2009. 
Haughton, J. and S. R. Khandker (2009), "Handbook on Poverty and Inequality", The International Bank for Reconstruction and Development/The World Bank, Pg:1-335.

Hidefumi, K. and M. Yuichi, (2009), "Aid Effectiveness, Governance and Public Investment”, The Research Institute of Economy, Trade and Industry, RIETI Discussion Paper Series 09-E-055, Pg:1-5.

Holden E., K. Linnerud and D. Banister (2017), "The Imperatives of Sustainable Development" Sustainable Development, May/June 2017, Volume 25, Issue 3, Pg:213-226.

International Fund for Agricultural Development (IFAD), (2010), "Rural Poverty Report 2011-New realities, new challenges: new opportunities for tomorrow's generation", November 2010, Pg:42-71.

Jahan, S. (2005), “Evolution of Human Development Index”, edi. Fukuda-Parr, Sakiko ; Kumar, A.K. Shiva, Readings in Human Development, s. 152-163, Oxford University Press.

Jayasuriya, R. and Q. Wodon (2003), "Efficiency in Reaching the Millennium Development Goals", World Bank Working Paper No. 9, The World Bank Washington, D.C., Pg:1-80.

Kizilaslan N., A. Z. Gürler and H. Kizilaslan (2007), "An analytical approach to sustainable development in Turkey", Sustainable Development, July/August 2007, Volume 15, Issue 4, Pg:254-266.

Kurniawan R., S. Managi (2017), "Sustainable Development and Performance Measurement: Global Productivity Decomposition", Sustainable Development, November/December 2017, Volume 25, Issue 6, Pg:639-654.

McGillivray, M. (2008), "Achieving the Millennium Development Goals" Published by Palgrave Macmillan in association with the United Nations University -World Institute for Development Economics Research, Studies in Development Economics and Policy, General Editor Anthony Shorrocks, Hampshire, England, Pg:1-144.

Piketty, T. (2014), “Capital in the Twenty-First Century”, Translated by Arthur Goldhammer, The Belknap Press of Harvard University Press, Cambridge, Massachusetts London, England, 2014.

Quental N., J. M. Lourenço, F. Nunes da Silva (2011), "Sustainable development policy: goals, targets and political cycles" Sustainable Development, January/February 2011, Volume 19, Issue 1, Pg:15-29.

Ramos T. B., S. Caeiro, S. M. Pires, N. Videira (2018), "How are new sustainable development approaches responding to societal challenges?”, Sustainable Development, March/April 2018, Volume 26, Issue 2, Pg:117-121.

Reddy, S.G \& A. Heuty (2006), "Achieving the Millennium Development Goals: What's wrong with existing analytical models?", Economic \& Social Affairs, DESA Working Paper No. 30, ST/ESA/2006/DWP/30, September 2006, Pg:1-25.

Spangenberg J. H. (2004), "Reconciling sustainability and growth: criteria, indicators, policies", Sustainable Development, May 2004, Volume 12, Issue 2, Pg:74-86.

Stiglitz, J. E., (2014), “Eşitsizliğin Bedeli: Bugünün Bölünmüss Toplumu Geleceğimizi Nasıl Tehlikeye Atıyor?”, İletişim Press / Politika Dizisi, İstanbul, 2014, Pg:1-375.

Şenses, F, (2003), “Küreselleşmenin Öteki Yüzü:Yoksulluk”, İletişim yayınları, İstanbul, 6.Baskı 2013, Pg:63-99. 
UNDP, (2009), "Human Development Report 2009-Overcoming Barriers: Human Mobility and Development", New York, USA, 2009.

UNDP, (2010), "Human Development Report 2010-The Real Wealth of Nations: Pathways to Human Development”, New York, USA, 2010.

UNDP, (2011), “Human Development Report 2011-Sustainability and Equity: A Better Future for All”, New York, USA, 2011.

UNDP, (2013), "Human Development Report 2013-The Rise of the South: Human Progress in a Diverse World”, New York, USA, 2013.

UNDP, (2014), "Human Development Report 2014- Sustaining Human Progress: Reducing Vulnerabilities and Building Resilience”, New York, USA, 2014.

United Nation (UN), (2012/a), "Official list of BKH indicators", Effective 15 January 2008, http://unstats.un.org/unsd/BKH/host.aspx?content=indicators/officiallist.htm, [Retrieved, 30.12.2012] .

United Nation (UN), (2012/b), “Millennium Development Goals Report 2012”, UN, New York.

United Nation (UN), (2014/a), “Millennium Development Goals Report 2014”, UN, New York.

United Nation (UN), (2014/b), "MDG Gap Task Force Report 2014, Millennium Development Goal 8, The State of the Global Partnership for Development”, UN, New York, 2014, Pg:1-75.

United Nation (UN), (2017), "Sustainable Development Goals: 17 Goals to Transform Our World" http://www.un.org/sustainabledevelopment/, [Retrieved, 07.02.2017]

Wichaisri S., A. Sopadang (2018), “Trends and Future Directions in Sustainable Development", Sustainable Development, January/February 2018, Volume 26, Issue 1, Pg:1-17.

World Bank, (1990), “World Development Report 1990: Poverty”,Washington, D.C.

World Bank, (2014/a), “World Development Indicators 2014 Book”, Washington, D.C. First printing April 2014.

World Bank, (2014/b), “World Development Indicators Online”, http://data.worldbank.org/datacatalog/world-development-indicators, [Retrieved:13.08.2014].

World Bank, (2014/c), "Millennium Development Goals Online”, http://data.worldbank.org/datacatalog/millennium-development-indicators [Retrieved:15.08.2014].

World Economic Forum, (2014), "The Global Gender Gap Report 2013”, Part 1: Measuring the Global Gender Gap: The Global Gender Gap Index 2013, Ricardo Hausmann, Harvard University, Laura D. Tyson, University of California, Berkeley, Yasmina Bekhouche, World Economic Forum and Saadia Zahidi, World Economic Forum, Pg: 1-5.

Xue L., L. Weng and H. Yu (2018) "Addressing policy challenges in implementing Sustainable Development Goals through an adaptive governance approach: A view from transitional China", Sustainable Development, March/April 2018, Volume 26, Issue 2, Pg:150-158. 
Table 1: MDGs Goals, Number of Related Targets and Indicators

\begin{tabular}{|l|c|c|}
\hline \multicolumn{1}{|c|}{ MDGs } & \# of Targets & \# of Indicators \\
\hline MDG 1: Eradicate extreme poverty and hunger & 3 & 9 \\
\hline MDG 2: Achieve Universal Primary Education & 1 & 3 \\
\hline MDG 3: Promote Gender Equality And Empower Women & 1 & 3 \\
\hline MDG 4: Reduce Child Mortality & 1 & 3 \\
\hline MDG 5: Improve Maternal Health & 2 & 6 \\
\hline MDG 6: Combat HIV/AIDS, Malaria, and Other Diseases & 3 & 10 \\
\hline MDG 7: Ensure Environmental Sustainability & 4 & 10 \\
\hline MDG 8. Develop a Global Partnership for Development & 6 & 16 \\
\hline & $\mathbf{2 1}$ & $\mathbf{6 0}$ \\
\hline
\end{tabular}

Source: UN, 2012/a, Official list of BKH indicators, Effective 15 January 2008 Retrieved 30.12.2013 http://unstats.un.org/unsd/BKH/host.aspx?content=indicators/officiallist.htm

Table 2: Dimensions and Indicators of Some Development and Poverty Indexes

\begin{tabular}{|c|c|c|c|c|c|c|c|c|}
\hline \multirow[t]{2}{*}{$\begin{array}{l}\text { Dimensions } \\
\text { /Indicators }\end{array}$} & \multicolumn{2}{|c|}{$\begin{array}{c}\text { Human Development } \\
\text { Index (HDI) }\end{array}$} & \multicolumn{2}{|c|}{$\begin{array}{l}\text { Human Poverty } \\
\text { Index (HPI-1) }\end{array}$} & \multicolumn{2}{|c|}{$\begin{array}{c}\text { Gender Development } \\
\text { Index (GDI) }\end{array}$} & \multicolumn{2}{|c|}{$\begin{array}{c}\text { Multidimensional } \\
\text { Poverty Index (MPI) }\end{array}$} \\
\hline & Dimension & Indicator & Dimension & Indicator & Dimension & Indicator & Dimension & Indicator \\
\hline $\begin{array}{c}\text { Income } \\
\text { (Standard of Living) }\end{array}$ & + & 1 & & & & & + & 6 \\
\hline Education & + & 2 & & & & & + & 2 \\
\hline Health & + & 1 & & & & & + & 2 \\
\hline Long and healthy life & & & + & 1 & + & 2 & & \\
\hline Knowledge & & & + & 1 & + & 4 & & \\
\hline $\begin{array}{l}\text { A decent standard of } \\
\text { living }\end{array}$ & & & + & 1 & + & 2 & & \\
\hline Social Exclusion & & & + & 1 & & & & \\
\hline $\begin{array}{c}\text { \#Total Dimension/ } \\
\text { Indicator }\end{array}$ & 3 & 4 & 4 & 4 & 3 & 8 & 3 & 10 \\
\hline
\end{tabular}

Sources: Compiled from various tables published by the UNDP \& World Bank 
Table 3: Dimensions and Related Indicators of UNDP Development \& Poverty Indexes

\begin{tabular}{|c|c|c|c|}
\hline \multirow[t]{2}{*}{ Indexes/ Method } & \multicolumn{3}{|c|}{ Dimensions \& Related Indicators } \\
\hline & $\begin{array}{l}\text { Income- A decent } \\
\text { standard of living }\end{array}$ & $\begin{array}{l}\text { Education- } \\
\text { Knowledge }\end{array}$ & $\begin{array}{l}\text { Health- Long and } \\
\text { healthy life }\end{array}$ \\
\hline $\begin{array}{l}\text { Human Development } \\
\text { Index (HDI) \& } \\
\text { Inequality-adjusted } \\
\text { Human Development } \\
\text { Index (IHDI) } \\
3 \text { Dimensions } \\
4 \text { Indicators } \\
\text { Geometric Mean }\end{array}$ & - GNI per capita (PPP \$) & $\begin{array}{l}\text { - Mean years of } \\
\text { schooling } \\
\text { - Expected years of } \\
\text { schooling } \\
\text { Education index is } \\
\text { calculate by using } \\
\text { arithmetic mean }\end{array}$ & - Life expectancy at birth \\
\hline $\begin{array}{c}\text { Gender Development } \\
\text { Index (GDI) } \\
3 \text { Dimensions } \\
3 \text { Indicators } \\
\text { Geometric Mean }\end{array}$ & - GNI per capita (PPP \$) & $\begin{array}{l}\text { - Adult literacy } \\
\text { - School enrollment }\end{array}$ & - Life expectancy at birth \\
\hline $\begin{array}{l}\text { Human Poverty } \\
\text { Index (HPI-1) } \\
3 \text { Dimensions } \\
4 \text { Indicators } \\
\text { Arithmetic Mean }\end{array}$ & $\begin{array}{l}\text { - Unweighted average of } \\
\text { population without } \\
\text { sustainable access to an } \\
\text { improved water source } \\
\text { - children under weight for } \\
\text { age }\end{array}$ & - Adult literacy & $\begin{array}{l}\text { - Probability at birth of not } \\
\text { surviving to age } 40\end{array}$ \\
\hline $\begin{array}{c}\text { Multidimensional } \\
\text { Poverty Index (MPI) } \\
3 \text { Dimensions } \\
\text { 10 Indicators } \\
\text { Geometric Mean }\end{array}$ & $\begin{array}{l}\text { - Cooking fuel } \\
\text { - Toilet } \\
\text { - Water } \\
\text { - Electricity } \\
\text { - Floor } \\
\text { - Assets } \\
\end{array}$ & $\begin{array}{l}\text { - Years of schooling } \\
\text { - Children enrolled }\end{array}$ & $\begin{array}{l}\text { - Child mortality } \\
\text { - Nutrition }\end{array}$ \\
\hline $\begin{array}{c}\text { Gender Inequality } \\
\text { Index (GII) } \\
\text { 3 Dimensions } \\
5 \text { Indicators } \\
\text { Geometric \& Harmonic } \\
\text { Mean }\end{array}$ & $\begin{array}{l}\text { Dimension 1: Labor } \\
\text { market } \\
\text { - Female and male labor } \\
\text { force participation rates }\end{array}$ & $\begin{array}{l}\text { Dimension 2: } \\
\text { Empowerment } \\
\text { - Female and male } \\
\text { shares of } \\
\text { parliamentary seats } \\
\text { - Female \& male } \\
\text { population with at least } \\
\text { secondary education }\end{array}$ & $\begin{array}{l}\text { Dimension 3: Reproductive } \\
\text { Health } \\
\text { - Maternal mortality ratio } \\
\text { - Adolescent fertility rate }\end{array}$ \\
\hline $\begin{array}{l}\text { * Global Gender Gap } \\
\text { Index } \\
\text { (GGGI) }\end{array}$ & $\begin{array}{l}\text { Dimension 1: Economic } \\
\text { Participation And } \\
\text { Opportunity } \\
\text { - Ratio: female labor force } \\
\text { participation over male } \\
\text { value } \\
\text { - Wage equality between } \\
\text { women and men for similar } \\
\text { work \& Ratio: female } \\
\text { estimated earned income } \\
\text { over male value fegislators, } \\
\text { - Ratio: female legials and } \\
\text { senior officials value } \\
\text { managers over male value } \\
\text { - Ratio: female professional } \\
\text { and technical workers over } \\
\text { male value }\end{array}$ & $\begin{array}{l}\text { Dimension 2: } \\
\text { Educational } \\
\text { Attainment } \\
\text { - Ratio: female literacy } \\
\text { rate over male value } \\
\text { - Ratio: female net } \\
\text { primary enrolment rate } \\
\text { over male value } \\
\text { - Ratio: female net } \\
\text { secondary enrolment } \\
\text { rate over male value } \\
\text { - Ratio: female gross } \\
\text { tertiary enrolment ratio } \\
\text { over male value }\end{array}$ & $\begin{array}{l}\text { Dimension 3: Health and } \\
\text { Survival } \\
\text { - Sex ratio at birth (converted to } \\
\text { female-over-male ratio) } \\
\text { - Ratio: female healthy life } \\
\text { expectancy over male value } \\
\text { Dimension 4: Political } \\
\text { Empowerment } \\
\text { - Ratio: females with seats in } \\
\text { parliament over male value } \\
\text { - Ratio: females at ministerial } \\
\text { level over male value } \\
\text { - Ratio: number of years with a } \\
\text { female head of state (last } 50 \\
\text { years) over male value }\end{array}$ \\
\hline
\end{tabular}

Sources: Compiled from various tables and documents: UNDP, Human Development Reports 2013 and 2014; UNDP Website; (*): World Economic Forum, The Global Gender Gap Report 2013, pg:1-5 
Table 4: Measurement of the Development Level of the Countries for "Net Primary Enrolment Ratio" Indicator

\begin{tabular}{|c|c|c|c|c|}
\hline $\begin{array}{c}\text { Max- }(0.2 * \mathrm{SD}) \\
<=\mathrm{I}<=\mathrm{Max}\end{array}$ & $\begin{array}{c}\text { Max- }(1 * \mathrm{SD})<=\mathrm{I}<= \\
\text { Max- }(0.2 * \mathrm{SD})\end{array}$ & $\begin{array}{c}\text { Max }-(2 * \mathrm{SD})<=\mathrm{I}<= \\
\text { Max }-(1 * \mathrm{SD})\end{array}$ & $\begin{array}{c}\text { Max }-(3 * \mathrm{SD})<=\mathrm{I}<= \\
\text { Max- }(2 * \mathrm{SD})\end{array}$ & Min \\
\hline 0.975 & 0.877 & 0.754 & 0.631 & 0.486 \\
\hline VERY HIGH & HIGH & MEDIUM & LOW & VERY LOW \\
\hline $0.975<=\mathrm{I}<=1$ & $0.877<=\mathrm{I}<0.975$ & $0.754<=\mathrm{I}<0.877$ & $0.631<=\mathrm{I}<0.754$ & $\mathrm{I}<0.631$ \\
\hline
\end{tabular}

I:MDG Index= Millennium Development Goals Index

Max: Maximum Value of the data set $=1$

Min: Minimum Value of the data set $=0.486$

$\mathrm{SD}=$ Standard Deviation of the data set $=0.122$

Table 5: Weight of Each MDGs in the Calculation of General MDGs Index

\begin{tabular}{|c|c|c|c|c|}
\hline MDGs & $\begin{array}{c}\text { Standard } \\
\text { Deviation of } \\
\text { MDGs (A) }\end{array}$ & $\begin{array}{c}\text { Standard Deviation for } \\
\text { every \% 1 Change } \\
(\mathrm{B}=0.01 / \mathrm{A})\end{array}$ & $\begin{array}{c}\text { Weight } \\
(\mathrm{C}=\mathrm{B} / \mathbf{0 . 6 3 7 7})\end{array}$ & $\begin{array}{l}\text { Weight \% } \\
(\mathrm{D}=\mathrm{C} * 100)\end{array}$ \\
\hline MDG 1 & 0.1372 & 0.0729 & 0.1143 & $11.4265 \%$ \\
\hline MDG 2 & 0.1161 & 0.0862 & 0.1351 & $13.5106 \%$ \\
\hline MDG 3 & 0.1328 & 0.0753 & 0.1181 & $11.8072 \%$ \\
\hline MDG 4 & 0.1077 & 0.0928 & 0.1455 & $14.5549 \%$ \\
\hline MDG 5 & 0.1465 & 0.0683 & 0.1071 & $10.7065 \%$ \\
\hline MDG 6 & 0.1033 & 0.0968 & 0.1518 & $15.1796 \%$ \\
\hline MDG 7 & 0.1253 & 0.0798 & 0.1252 & $12.5187 \%$ \\
\hline MDG 8 & 0.1523 & 0.0657 & 0.1030 & $10.2960 \%$ \\
\hline \multicolumn{2}{|c|}{ TOTAL } & 0.6377 & 1.00 & $100.00 \%$ \\
\hline
\end{tabular}

Table 6: Measurement of the Success Level of the Countries for "Net Primary Enrolment Ratio Indicator

\begin{tabular}{|c|c|c|c|c|}
\hline $\begin{array}{c}\operatorname{Max}-(0.2 * \mathrm{SD})<= \\
\operatorname{MDG}<=\operatorname{Max}\end{array}$ & $\begin{array}{c}\operatorname{Max}-(1 * \mathrm{SD})<= \\
\mathrm{MDG}<=\mathrm{Max}- \\
(0.2 * \mathrm{SD})\end{array}$ & $\begin{array}{c}\operatorname{Max}-(2 * \mathrm{SD})<= \\
\mathrm{MDG}<=\mathrm{Max}- \\
(1 * \mathrm{SD})\end{array}$ & $\begin{array}{c}\operatorname{Max}-(3 * \mathrm{SD})<= \\
\mathrm{MDG}<=\operatorname{Max}-(2 * \mathrm{SD})\end{array}$ & Min \\
\hline 98.1630 & 90.8149 & 81.6298 & 72.4446 & 37.8300 \\
\hline VERY SUCCESFUL & SUCCESSFUL & $\begin{array}{l}\text { PARTIALLY } \\
\text { SUCCESSFUL }\end{array}$ & $\begin{array}{c}\text { PARTIALLY } \\
\text { UNSUCCESSFUL }\end{array}$ & UNSUCCESSFUL \\
\hline$\overline{998.16<=\mathrm{MDG}<=100}$ & 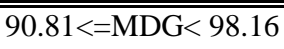 & $81.63<=$ MDG $<90.81$ & $\overline{772.44<=M D G<81.63}$ & MDG < 72.44 \\
\hline
\end{tabular}

MDG= Millennium Development Goals Success Level

Max: Maximum Success Level of the data set $=100$

Min: Minimum Success Level of the data set $=37.83$

$\mathrm{SD}=$ Standard Deviation of the data set $=9.19$ 
Table 7: Weight of Each MDGs in the Calculation of General MDGs Success Level

\begin{tabular}{|c|r|r|r|r|}
\hline MDGs & $\begin{array}{c}\text { Standard } \\
\text { Deviation of } \\
\text { MDGs (A) }\end{array}$ & $\begin{array}{c}\text { Standard Deviation for } \\
\text { every \%1 Change } \\
(\mathbf{B = 0 . 0 1 / A )}\end{array}$ & $\begin{array}{c}\text { Weight } \\
(\mathbf{C}=\mathbf{B} / \mathbf{0 . 0 0 7 5 6 9 )})\end{array}$ & $\begin{array}{c}\text { Weight \% } \\
(\mathbf{D}=\mathbf{C} * \mathbf{1 0 0})\end{array}$ \\
\hline MDG 1 & 8.569288 & 0.001167 & 0.1542 & $15.4165 \%$ \\
\hline MDG 2 & 9.688065 & 0.001032 & 0.1364 & $13.6362 \%$ \\
\hline MDG 3 & 11.45462 & 0.000873 & 0.1153 & $11.5332 \%$ \\
\hline MDG 4 & 12.83802 & 0.000779 & 0.1029 & $10.2904 \%$ \\
\hline MDG 5 & 12.49072 & 0.000801 & 0.1058 & $10.5765 \%$ \\
\hline MDG 6 & 10.47412 & 0.000955 & 0.1261 & $12.6128 \%$ \\
\hline MDG 7 & 9.609839 & 0.001041 & 0.1375 & $13.7472 \%$ \\
\hline MDG 8 & 10.83994 & 0.000923 & 0.1219 & $12.1872 \%$ \\
\hline & & $\mathbf{0 . 0 0 7 5 6 9}$ & & $\mathbf{1 0 0 . 0 0 \%}$ \\
\hline
\end{tabular}

Table 8: The Results of Each MDG Index, Rankings and Development Level of Countries Calculated by the Weighted Averaged Method (2015)*

\begin{tabular}{|c|c|c|c|c|c|c|c|c|c|c|c|}
\hline $\begin{array}{l}\text { Countries/ } \\
\text { MDGs General } \\
\text { Index Value } \\
\text { and Rank }\end{array}$ & $\begin{array}{l}\text { MDG } \\
\text { Index } \\
\text { Value } \\
(2015)\end{array}$ & $\begin{array}{l}\text { MDG } \\
\text { Rank } \\
2015\end{array}$ & $\begin{array}{c}\text { MDG } \\
\text { DEVELOPME } \\
\text { NT } \\
\text { LEVEL }\end{array}$ & $\begin{array}{c}\text { MDG } 1 \\
\text { POVERT } \\
Y\end{array}$ & $\begin{array}{c}\text { MDG } 2 \\
\text { EDUCAT } \\
\text { ION }\end{array}$ & $\begin{array}{c}\text { MDG } 3 \\
\text { GENDER } \\
\text { EQUALI } \\
\text { TY }\end{array}$ & $\begin{array}{l}\text { MDG } 4 \\
\text { CHILD } \\
\text { HEALTH }\end{array}$ & $\begin{array}{c}\text { MDG } 5 \\
\text { MATERNAL } \\
\text { HEALTH }\end{array}$ & $\begin{array}{c}\text { MDG } 6 \\
\text { HIV/AIDS } \\
\text { OTHER } \\
\text { DISEASES }\end{array}$ & $\begin{array}{l}\text { MDG } 7 \\
\text { ENVIRO } \\
\text { NMENT }\end{array}$ & $\begin{array}{c}\text { MDG } 8 \\
\text { GLOBAL } \\
\text { PARTNER } \\
\text { SHIP }\end{array}$ \\
\hline Sweden & 0.9764 & 1 & VERY HIGH & 9 & 16 & 5 & 9 & 9 & 1 & 15 & 13 \\
\hline Germany & 0.9663 & 2 & VERY HIGH & 14 & 21 & 14 & 15 & 17 & 33 & 5 & 7 \\
\hline Netherlands & 0.9656 & 3 & VERY HIGH & 17 & 24 & 6 & 21 & 5 & 15 & 22 & 11 \\
\hline Switzerland & 0.9596 & 5 & VERY HIGH & 12 & 74 & 29 & 55 & 1 & 23 & 7 & 2 \\
\hline South Korea & 0.9169 & 32 & $\mathrm{HIGH}$ & 24 & 32 & 101 & 1 & 6 & 26 & 76 & 43 \\
\hline Mexico & 0.8911 & 47 & $\mathrm{HIGH}$ & 86 & 40 & 28 & 61 & 96 & 74 & 44 & 76 \\
\hline Argentina & 0.8868 & 49 & $\mathrm{HIGH}$ & 72 & 47 & 21 & 85 & 75 & 89 & 92 & 56 \\
\hline Russia & 0.8864 & 51 & $\mathrm{HIGH}$ & 49 & 26 & 74 & 36 & 52 & 118 & 108 & 26 \\
\hline Turkey & 0.8419 & 97 & MEDIUM & 100 & 37 & 141 & 51 & 94 & 60 & 109 & 110 \\
\hline Indonesia & 0.8012 & 122 & MEDIUM & 128 & 80 & 114 & 132 & 128 & 151 & 96 & 114 \\
\hline South Africa & 0.7653 & 135 & LOW & 140 & 133 & 18 & 135 & 112 & 184 & 159 & 62 \\
\hline India & 0.7379 & 142 & LOW & 167 & 121 & 163 & 149 & 136 & 110 & 137 & 120 \\
\hline Liberia & 0.6050 & 183 & VERY LOW & 185 & 185 & 161 & 160 & 183 & 133 & 172 & 170 \\
\hline Congo Dem. & 0.5990 & 184 & VERY LOW & 184 & 180 & 181 & 184 & 159 & 154 & 141 & 180 \\
\hline Sierra Leone & 0.5841 & 185 & VERY LOW & 159 & 179 & 175 & 186 & 176 & 181 & 164 & 163 \\
\hline C. African Rep. & 0.5619 & 186 & VERY LOW & 171 & 184 & 174 & 187 & 182 & 175 & 160 & 184 \\
\hline Chad & 0.5441 & 187 & VERY LOW & 153 & 186 & 186 & 183 & 187 & 160 & 180 & 167 \\
\hline
\end{tabular}

*MDGs index (also sub-indexes for every indicators, targets and goals) is created by considering 187 countries for the period of 1990-2015. 
Table 9: MDGs Success Level of the Countries and Their Ranks (2015)*

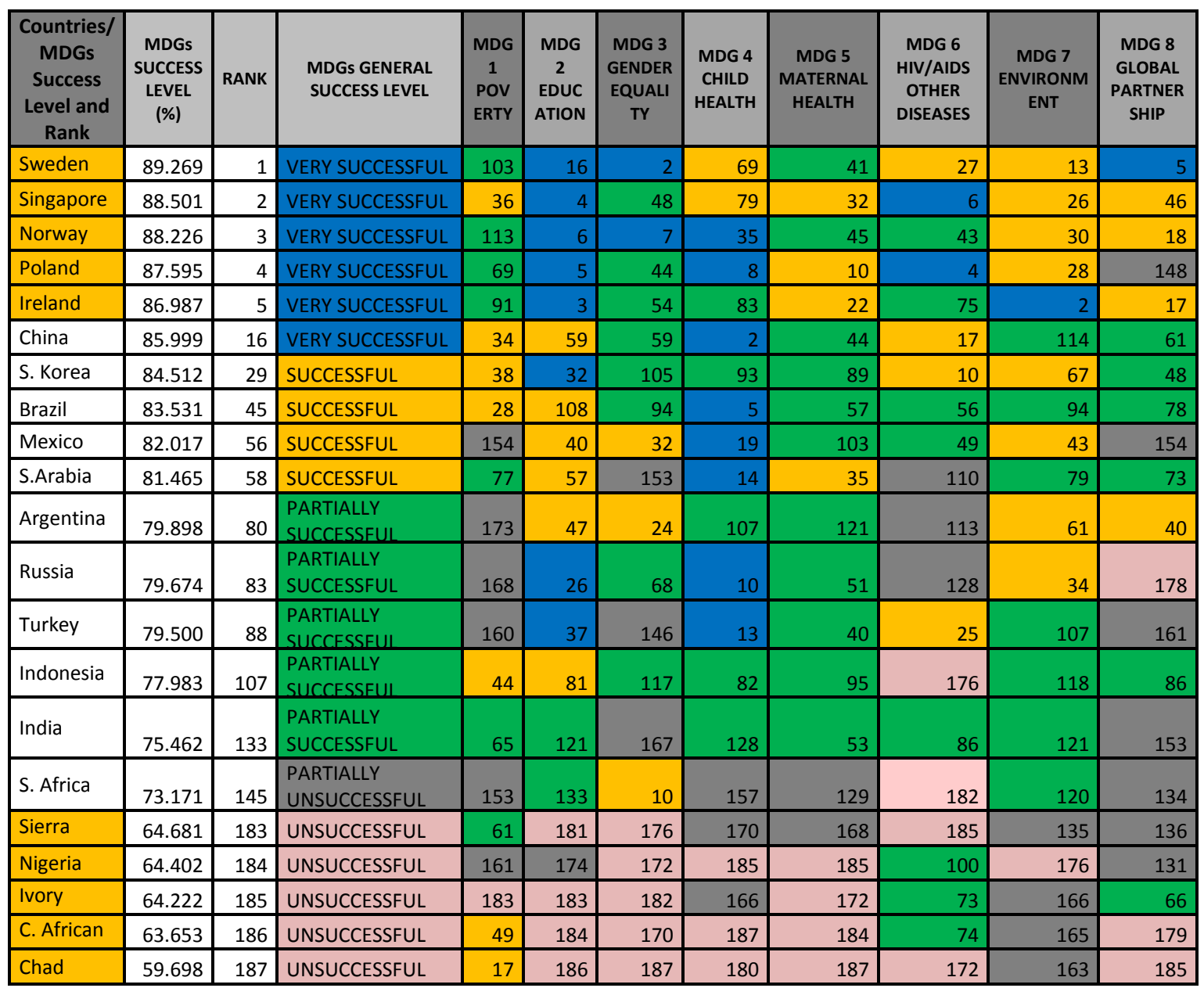

*MDGs success level (also success level for every indicators, targets and goals) is created by considering 187 countries for the period of 1990-2015. 
Table 10: Compression of the MDGs Results with Extended MDGs Results

\begin{tabular}{|c|c|c|c|c|c|c|c|c|}
\hline \multirow[b]{2}{*}{ COUNTRIES } & \multicolumn{3}{|c|}{ MDGs INDEX RESULTS (2013) } & \multicolumn{3}{|c|}{$\begin{array}{l}\text { EXTENDED MDGS INDEX (E-MDGs) } \\
\text { RESULTS ( } 2013\end{array}$} & \multicolumn{2}{|c|}{$\begin{array}{l}\text { COMPARISON of E-MDGs \& } \\
\text { MDGs }\end{array}$} \\
\hline & $\begin{array}{l}\text { MDGs } \\
\text { Index }\end{array}$ & $\begin{array}{l}\text { MDGs } \\
\text { RANK }\end{array}$ & $\begin{array}{c}\text { MDGs } \\
\text { DEVELOPMENT } \\
\text { LEVELS (2013) }\end{array}$ & $\begin{array}{l}\text { E-MDGs } \\
\text { Index }\end{array}$ & $\begin{array}{l}\text { E-MDGs } \\
\text { RANK }\end{array}$ & $\begin{array}{c}\text { E-MDGs } \\
\text { DEVELOPMENT } \\
\text { LEVELS (2013) }\end{array}$ & $\begin{array}{l}\text { (E-MDGs) } \\
- \text { (MDGs) } \\
\text { Index }\end{array}$ & $\begin{array}{l}\text { (E-MDGs Rank) } \\
\text { - (MDGs Rank) }\end{array}$ \\
\hline Barbados & 0.913 & 33 & HIGH & 0.852 & 56 & HIGH & -0.061 & -23 \\
\hline Brunei Dar. & 0.916 & 30 & $\mathrm{HIGH}$ & 0.943 & 7 & VERY HIGH & 0.027 & 23 \\
\hline Central Africa & 0.544 & 186 & VERY LOW & 0.445 & 187 & VERY LOW & -0.099 & -1 \\
\hline Chad & 0.514 & 187 & VERY LOW & 0.481 & 185 & VERY LOW & -0.033 & 2 \\
\hline China & 0.866 & 66 & HIGH & 0.813 & 75 & MEDIUM & -0.054 & -9 \\
\hline Congo Dem. $\mathrm{R}$ & 0.577 & 184 & VERY LOW & 0.451 & 186 & VERY LOW & -0.126 & -2 \\
\hline Costa Rika & 0.894 & 42 & HIGH & 0.837 & 63 & $\mathrm{HIGH}$ & -0.057 & -21 \\
\hline Ecuador & 0.870 & 59 & HIGH & 0.808 & 80 & MEDIUM & -0.062 & -21 \\
\hline Equatorial Guinea & 0.690 & 152 & LOW & 0.735 & 120 & MEDIUM & 0.044 & 32 \\
\hline Germany & 0.960 & 2 & VERY HIGH & 0.944 & 6 & VERY HIGH & -0.016 & -4 \\
\hline Grenada & 0.879 & 51 & $\mathrm{HIGH}$ & 0.815 & 72 & MEDIUM & -0.064 & -21 \\
\hline Kuwait & 0.871 & 58 & $\mathrm{HIGH}$ & 0.917 & 22 & VERY HIGH & 0.046 & 36 \\
\hline Liberian & 0.585 & 182 & VERY LOW & 0.485 & 184 & VERY LOW & -0.100 & -2 \\
\hline Liechtenstein & 0.894 & 43 & $\mathrm{HIGH}$ & 0.932 & 11 & VERY HIGH & 0.038 & 32 \\
\hline Luxembourg & 0.949 & 6 & VERY HIGH & 0.954 & 3 & VERY HIGH & 0.005 & 3 \\
\hline Malawi & 0.675 & 156 & LOW & 0.540 & 176 & VERY LOW & -0.135 & -20 \\
\hline Netherlands & 0.956 & 3 & VERY HIGH & 0.941 & 8 & VERY HIGH & -0.015 & -5 \\
\hline Nicaragua & 0.812 & 109 & MEDIUM & 0.724 & 129 & MEDIUM & -0.088 & -20 \\
\hline Niger & 0.579 & 183 & VERY LOW & 0.489 & 183 & VERY LOW & -0.090 & 0 \\
\hline Norway & 0.956 & 4 & VERY HIGH & 0.963 & 1 & VERY HIGH & 0.007 & 3 \\
\hline Oman & 0.854 & 74 & MEDIUM & 0.875 & 43 & HIGH & 0.021 & 31 \\
\hline Qatar & 0.870 & 60 & $\mathrm{HIGH}$ & 0.916 & 23 & VERY HIGH & 0.047 & 37 \\
\hline Sierra Leone & 0.557 & 185 & VERY LOW & 0.514 & 182 & VERY LOW & -0.043 & 3 \\
\hline Singapore & 0.936 & 19 & $\mathrm{HIGH}$ & 0.957 & 2 & VERY HIGH & 0.021 & 17 \\
\hline Slovenia & 0.948 & 7 & VERY HIGH & 0.911 & 27 & HIGH & -0.037 & -20 \\
\hline Sweden & 0.971 & 1 & VERY HIGH & 0.952 & 5 & VERY HIGH & -0.020 & -4 \\
\hline Switzerland & 0.955 & 5 & VERY HIGH & 0.953 & 4 & VERY HIGH & -0.002 & 1 \\
\hline Turkey & 0.835 & 94 & MEDIUM & 0.818 & 71 & MEDIUM & -0.017 & 23 \\
\hline U.A.E & 0.869 & 61 & $\mathrm{HIGH}$ & 0.902 & 31 & $\mathrm{HIGH}$ & 0.033 & 30 \\
\hline USA & 0.927 & 25 & $\mathrm{HIGH}$ & 0.934 & 10 & VERY HIGH & 0.007 & 15 \\
\hline WORLD AVERAGE & 0.795 & & MEDIUM & 0.775 & & MEDIUM & & \\
\hline
\end{tabular}

Note: Compression is based on E-MDGs Results. While positive values indicate E-MDGs have better results than MDGs results, negative values indicate opposite. 
Table 11: SDG Goals, Number of Related Targets

\begin{tabular}{|c|c|c|}
\hline SDGs & $\begin{array}{c}\text { \# of } \\
\text { Targets }\end{array}$ & $\begin{array}{c}\text { \# of } \\
\text { Indicators }\end{array}$ \\
\hline SDG 1: End poverty & 7 & 14 \\
\hline SDG 2: End hunger, achieve food security & 8 & 13 \\
\hline SDG 3: Ensure healthy lives and promote wellbeing for all at all ages & 13 & 27 \\
\hline SDG 4: Ensure inclusive and equitable quality education & 10 & 11 \\
\hline SDG 5: Achieve gender equality and empower all women and girls & 9 & 14 \\
\hline SDG 6: Ensure availability and sustainable management of water & 8 & 11 \\
\hline SDG 7: Ensure access to affordable, reliable, sustainable and modern energy & 5 & 6 \\
\hline SDG 8: Promote sustained, inclusive and sustainable economic growth & 12 & 17 \\
\hline $\begin{array}{l}\text { SDG 9: Build resilient infrastructure, promote inclusive and sustainable } \\
\text { industrialization }\end{array}$ & 8 & 12 \\
\hline SDG 10: Reduce inequality within and among countries & 10 & 11 \\
\hline $\begin{array}{l}\text { SDG 11: Make cities and human settlements inclusive, safe, resilient and } \\
\text { sustainable }\end{array}$ & 10 & 15 \\
\hline SDG 12: Ensure sustainable consumption and production patterns & 11 & 13 \\
\hline SDG 13: Take urgent action to combat climate change and its impacts & 5 & 8 \\
\hline SDG 14: Conserve and sustainably use the oceans, seas and marine resources & 10 & 10 \\
\hline SDG 15: Protect, restore and promote sustainable use of terrestrial ecosystems & 12 & 14 \\
\hline SDG 16: Promote peaceful and inclusive societies for sustainable develop. & 12 & 23 \\
\hline $\begin{array}{l}\text { SDG 17: Strengthen the means of implementation and revitalise the global } \\
\text { partnership }\end{array}$ & 19 & 25 \\
\hline TOTAI & 169 & 244* \\
\hline
\end{tabular}

Source: UN, 2017, Official list of SDG indicators, *: The total number of indicators listed in the final indicator proposal is 244 . However, since 9 indicators repeat under 2 or 3 different targets, the actual total number is 232 , Retrieved 18.05.2017, http://unstats.un.org/sdgs/indicators/indicators-list/ 


\section{Appendix}

Appendix 1: General MDGs Index (Development Level) of the Countries on World Map (2015)

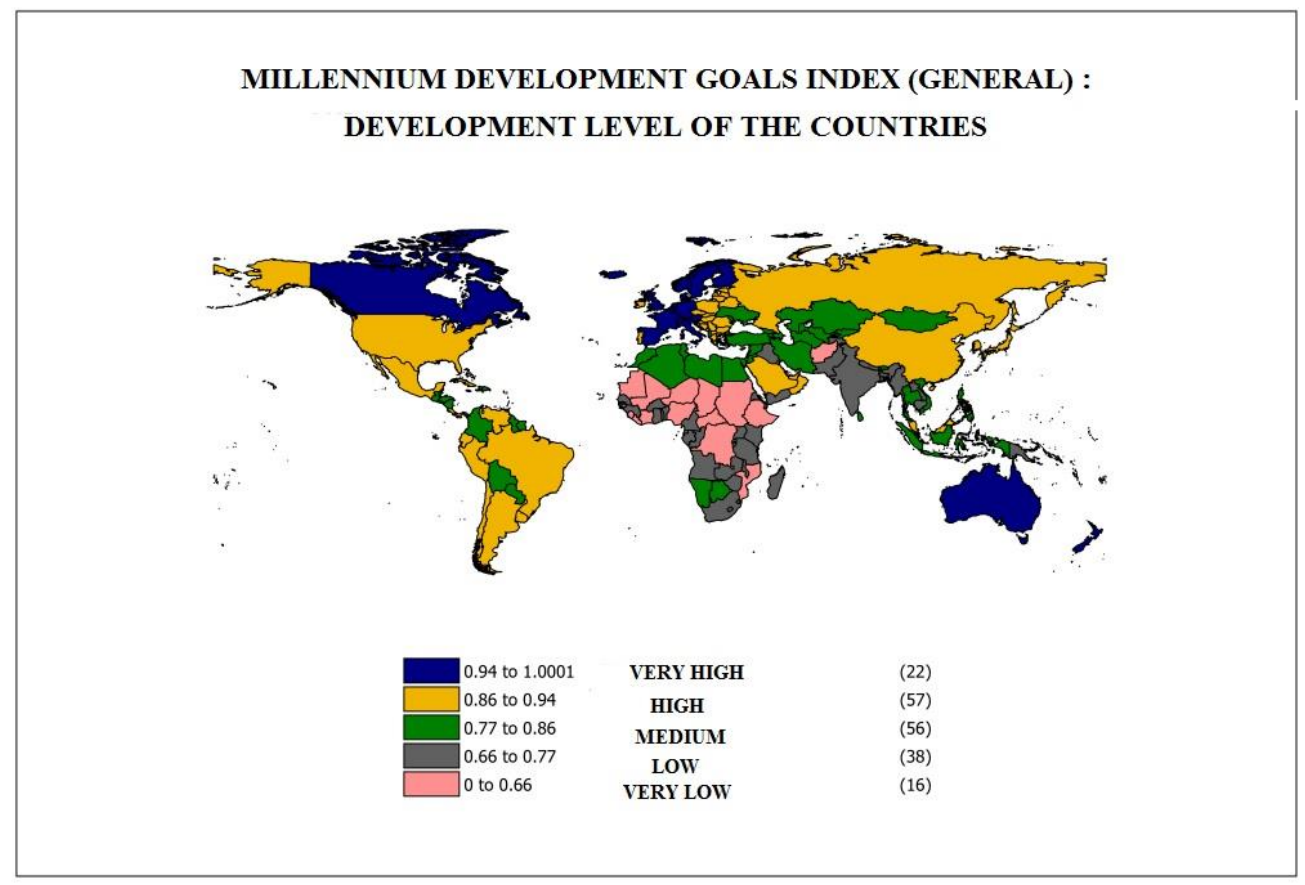

Appendix 2: MDGs Success Rate (Performance Levels) of the Countries on World Map (2015) MILLENNIUM DEVELOPMENT GOALS (GENERAL) SUCCESS/PERFORMANCE
LEVEL OF THE COUNTRIES
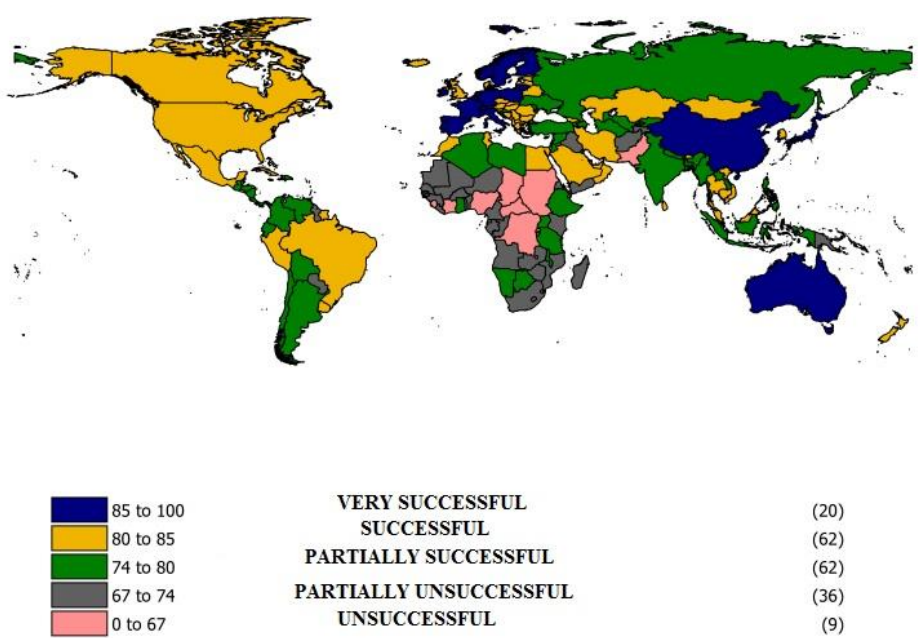
Appendix 3: Comparing the Results and Rank of the Countries (Calculated by Weighted Average Method) MDGs Index (Development Level) and the MDGs Success Rate (Performance Levels) 2015

\begin{tabular}{|c|c|c|c|c|c|c|c|c|c|c|c|c|c|c|c|c|c|c|c|c|c|c|}
\hline \multirow{2}{*}{ 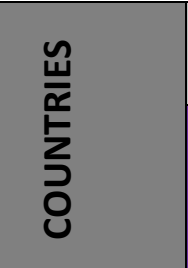 } & \multicolumn{11}{|c|}{$\begin{array}{c}\text { COUNTRIES RANK AND DEVELOPMET LEVELS FOR } \\
\text { GENERAL AND EACH MDGs* }\end{array}$} & \multicolumn{11}{|c|}{$\begin{array}{l}\text { COUNTRIES RANK AND PERFORMANCE LEVELS FOR GENERAL AND } \\
\text { EACH MDGs** }\end{array}$} \\
\hline & $\begin{array}{c}\text { MDGs } \\
\text { GENERAL } \\
\text { DEVELOPMET } \\
\text { LEVELS }\end{array}$ & $\begin{array}{l}\text { INDEX } \\
\text { VALUE }\end{array}$ & $\begin{array}{l}\text { MDGs } \\
\text { GENE } \\
\text { RAL } \\
\text { RANK }\end{array}$ & 至光 & 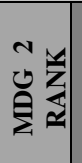 & 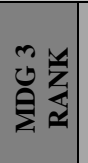 & 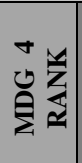 & 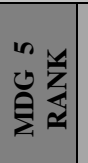 & 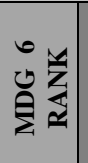 & 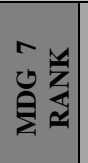 & 言东 & $\begin{array}{l}\text { MDGs GENERAL } \\
\text { PERFORMANCE LEVELS }\end{array}$ & \begin{tabular}{c|c} 
SUCCESS & I \\
RATE &
\end{tabular} & $\begin{array}{l}\text { MDGs } \\
\text { GENE } \\
\text { RAL } \\
\text { RANK }\end{array}$ & 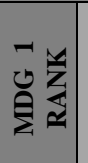 & 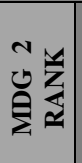 & 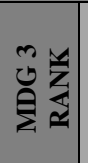 & 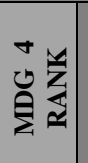 & 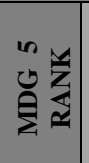 & 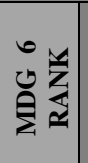 & 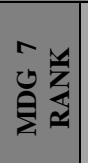 & 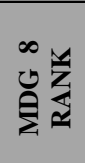 \\
\hline Afghanistan & VERY LOW & 6355 & 178 & 178 & 101 & 183 & 177 & 175 & 113 & 186 & 178 & PARTIALLY & 0368 & 164 & 102 & 104 & 184 & 159 & 144 & 90 & 178 & 120 \\
\hline Albania & MEDIUM & 3588 & 77 & 110 & 79 & 95 & 63 & 41 & 67 & 104 & 97 & SUCCESSFUL & 81,2 & 63 & 124 & 79 & 95 & 43 & 48 & 107 & 54 & 123 \\
\hline Algeria & MEDIUM & 424 & 96 & 113 & 68 & 115 & 91 & 78 & 104 & 112 & 69 & PARTIALLY & 77,9497 & 108 & 105 & 68 & 124 & 58 & 59 & 134 & 156 & 97 \\
\hline Andorra & HIGH & 16 & 39 & 4 & 169 & 8 & 26 & 57 & 4 & 59 & 25 & SUCCI & 84,7463 & 25 & 30 & 169 & 1 & 41 & 19 & 1 & 40 & 181 \\
\hline Angola & LOW & 0,6810 & 160 & 158 & 168 & 125 & 178 & 172 & 159 & 138 & 119 & PARTIALLY & 70,1539 & 168 & 9 & 168 & 129 & 151 & 134 & 170 & 173 & 162 \\
\hline Antigua Barb. & MEDIU & & 115 & 34 & 128 & 96 & 37 & 79 & 187 & 98 & 23 & PARTIALLY & 78,3202 & 105 & 37 & 128 & 91 & 73 & 33 & 187 & 60 & 42 \\
\hline Argentina & HIGH & & 49 & 72 & 47 & 21 & 85 & 75 & 89 & 92 & 56 & $\mathrm{PAF}$ & 79,8981 & 80 & 173 & 47 & 24 & 107 & 121 & 113 & 61 & 40 \\
\hline Armenia & $\overline{M E D I U}$ & & 90 & 55 & 106 & 113 & 72 & 93 & 80 & 84 & \begin{tabular}{|l|}
118 \\
\end{tabular} & $\mathrm{PAl}$ & 77,2977 & 118 & 52 & \begin{tabular}{l|l|}
106 \\
\end{tabular} & 110 & 22 & 114 & 159 & 128 & 143 \\
\hline Australia & VERY HIGH & 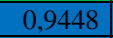 & 15 & 6 & 31 & 40 & 43 & 12 & 24 & 53 & 6 & VERY SUCCESS & 86,74066 & 9 & 60 & 31 & 43 & 118 & 49 & 16 & 25 & 13 \\
\hline Austria & VERY HIGH & 22 & 18 & 13 & 56 & 12 & 111 & 18 & 49 & 10 & 34 & SUCCESSFUL & 84,9459 & 22 & 130 & 55 & 16 & 101 & 4 & 114 & 70 & 19 \\
\hline Azerbaij: & MEDIUM & 29 & 95 & 74 & 39 & 84 & 146 & 117 & 43 & 145 & 51 & & 705 & 85 & 26 & 39 & 84 & 103 & 155 & 53 & 96 & 133 \\
\hline Bahama & HIGH & & 54 & 22 & 77 & 69 & 89 & 71 & 94 & 94 & 55 & & & 87 & 22 & 77 & 64 & 149 & 84 & 152 & 42 & 127 \\
\hline Bahrain & HIGH & 34 & 63 & 56 & 20 & 146 & 32 & 20 & 42 & 139 & 49 & SUCCESSFUL & 81,7735 & 57 & 128 & 20 & 142 & 62 & 61 & 48 & 57 & 59 \\
\hline Bangladesh & LOW & 0,7179 & 149 & 170 & 153 & 155 & 113 & 163 & 134 & 154 & 133 & PARTIALLY & 77,3434 & 117 & 41 & 153 & 157 & 31 & 125 & 77 & 95 & 130 \\
\hline Barbados & HIGH & & 34 & 38 & 28 & 54 & 107 & 66 & 7 & 100 & 9 & PART & 78 & 103 & 169 & 28 & 52 & 178 & 52 & 95 & 103 & 28 \\
\hline Belarus & HIGH & & 38 & 36 & 55 & 27 & 4 & 15 & 92 & 70 & 41 & SUCCESS & 82,7153 & 51 & 74 & 56 & 29 & 7 & 3 & 173 & 47 & 167 \\
\hline Belgium & VERY & & 10 & 28 & 27 & 9 & 18 & 3 & 81 & 11 & 10 & VERY SU & 85,04458 & 20 & 112 & 27 & 13 & 72 & 72 & 144 & 22 & \\
\hline Belize & MEDIUM & 0,8466 & 92 & 80 & 112 & 126 & 77 & 113 & 119 & 8 & 125 & PARTIALLY & 75,0564 & 135 & 136 & 112 & 122 & 76 & 98 & 165 & 46 & 183 \\
\hline Benin & LOW & & 157 & 131 & 159 & 184 & 169 & 153 & 98 & 127 & 156 & PARTI & 72 , & 149 & 35 & 159 & 183 & 135 & 147 & 78 & 184 & 10 \\
\hline Bhuta & $M$ & & 120 & 87 & 127 & 149 & 123 & 123 & 131 & 41 & 134 & SUCC & 80,2100 & 74 & 11 & 127 & 144 & 45 & 47 & 139 & 81 & 110 \\
\hline Bolivia & MEDIU. & 0,8086 & 118 & 146 & 110 & 67 & 133 & 134 & 137 & 71 & 94 & $\overline{\mathrm{PAF}}$ & (78,7647 & 100 & 182 & 110 & 76 & 66 & 93 & 59 & 115 & 32 \\
\hline Bosnia and Her & HIGH & 0,8623 & 76 & 106 & 82 & 55 & 23 & 55 & 64 & 135 & 100 & SUCCESSFUL & 81,4255 & 59 & 138 & 82 & 57 & 17 & 65 & 65 & 66 & 138 \\
\hline Botswana & MEDIU & 0,8061 & 119 & 130 & 65 & 121 & 131 & 106 & 174 & 73 & 77 & PARTIALLY & 77,5396 & 115 & \begin{tabular}{l|l}
89 \\
\end{tabular} & 65 & 116 & 173 & 110 & 13 & 157 & 75 \\
\hline Brazil & HIGH & & 70 & 104 & 108 & 98 & 46 & 82 & 87 & 25 & 63 & SUC & 83,5311 & 45 & 28 & 108 & 94 & 5 & 57 & 56 & 94 & 78 \\
\hline Brunei & $\mathrm{H}$ & & 29 & 11 & 11 & 37 & 22 & 46 & 85 & 49 & 40 & $\mathrm{PA}$ & 77,6886 & 114 & 139 & 11 & 14 & 139 & 78 & 125 & 158 & 113 \\
\hline Bulgaria & $\mathrm{H}$ & & 31 & 71 & 22 & 36 & 71 & 84 & 28 & 20 & 42 & SUC & 84,5015 & 30 & 73 & 22 & 38 & 109 & 102 & 15 & 39 & 63 \\
\hline Burkina Faso & LOW & 0,6727 & 163 & 175 & 178 & 156 & 170 & 157 & 112 & 144 & 146 & PARTIALLY & 71,1389 & 159 & 101 & 178 & 155 & 134 & 152 & 69 & 167 & 72 \\
\hline Burundi & LOW & & 167 & 181 & 149 & 136 & 158 & 165 & 82 & 171 & 185 & PARTIALLY & 70,8010 & 161 & 151 & 149 & 149 & 137 & 162 & 47 & 153 & 158 \\
\hline Cambodia & & 695 & 134 & 141 & 132 & 93 & 119 & 124 & 162 & 129 & 149 & SUCCESSFUL & 83,5496 & 44 & 19 & 132 & 97 & 47 & 38 & 52 & 132 & 21 \\
\hline Can & & & 146 & 144 & 155 & 110 & 161 & 177 & 97 & 118 & 111 & PART & & 154 & 134 & 156 & 119 & 161 & 180 & 120 & 142 & 57 \\
\hline Canada & VERY HIGH & 0,9476 & 13 & 10 & 1 & 31 & 13 & 16 & 18 & 54 & 21 & SUCCESSFUL & 83,9560 & 38 & 110 & 1 & 33 & 132 & 119 & 38 & 21 & 20 \\
\hline Cape Verde & MEDIUM & 0,8102 & 117 & 48 & 86 & 75 & 92 & 133 & 141 & 158 & 142 & SUCCESSFUL & 82,8817 & 50 & 14 & 86 & 74 & 49 & 100 & 85 & 139 & 41 \\
\hline Cent.African R & VERY LOW & 0,5619 & 186 & \begin{tabular}{l|l|}
171 \\
\end{tabular} & 184 & 174 & 187 & 182 & 175 & 160 & 184 & UNSUCCESSFUL & 63,65262 & 186 & 49 & 184 & 170 & 187 & 184 & 74 & 165 & 179 \\
\hline
\end{tabular}




\begin{tabular}{|c|c|c|c|c|c|c|c|c|c|c|c|c|c|c|c|c|c|c|c|c|c|c|}
\hline Chad & VERY LOW & 0,5441 & 187 & 153 & 186 & 186 & 183 & 187 & 160 & 180 & 167 & UNSUCCESSFUL & 59,69831 & 187 & 17 & 186 & 187 & 180 & 187 & 172 & 163 & 185 \\
\hline Chile & HIGH & 0,8707 & 68 & 61 & 91 & 102 & 94 & 80 & 125 & 52 & 48 & PARTIALLY SUCCESSFUL & 79,2405 & 92 & 24 & 91 & 104 & 121 & 75 & 145 & 149 & 38 \\
\hline China & \begin{tabular}{|l|} 
HIGH \\
\end{tabular} & 8738 & 62 & 107 & 59 & 51 & 41 & 50 & 53 & 132 & 74 & VERY SUCCESSFUL & 85,99871 & 16 & 34 & 59 & 59 & 2 & 44 & 17 & 114 & 61 \\
\hline Colombia & MEDIUM & 0,8515 & 85 & 121 & 120 & 89 & 79 & 89 & 121 & 28 & 84 & PARTIALLY SUCCESSFUL & 75,6447 & 131 & 144 & 120 & 88 & 91 & 107 & 135 & 134 & 121 \\
\hline Comoros & LOW & 0,6752 & 162 & 169 & 148 & 180 & 163 & 146 & 106 & 173 & 172 & UNSUCCESSFUL & 67,60592 & 178 & 119 & 148 & 178 & 162 & 150 & 178 & 171 & 107 \\
\hline Congo Dem. R & VERY LOW & 5990 & 184 & 184 & 180 & 181 & 184 & 159 & 154 & 141 & 180 & UNSUCCESSFUL & 65,99318 & 181 & 122 & 179 & 180 & 186 & 159 & 105 & 170 & 126 \\
\hline Congo, Rep. & LOW & 7208 & 148 & 156 & 125 & 166 & 171 & 149 & 170 & 87 & 109 & PARTIALLY UNSUCCESSFUL & 71,4756 & 153 & 39 & 125 & 166 & 182 & 146 & 142 & 133 & 132 \\
\hline Costa Rica & HIGH & 9050 & 42 & 98 & 62 & 19 & 48 & 103 & 58 & 13 & 66 & PARTIALLY SUCCESSFUL & 77,5283 & 116 & 141 & 62 & 18 & 127 & 143 & 115 & 123 & 104 \\
\hline Cote d'Ivoire & VERY LOW & 6462 & 176 & 154 & 183 & 182 & 176 & 173 & 152 & 103 & 157 & UNSUCCESSFUL & 64,22216 & 185 & 183 & 183 & 182 & 166 & 172 & 73 & 166 & 66 \\
\hline Croatia & HIGH & 9127 & 36 & 90 & 100 & 43 & 29 & 36 & 17 & 64 & 19 & PARTIALLY SUCCESS & 79,7078 & 82 & 177 & 100 & 45 & 33 & 118 & 2 & 44 & 180 \\
\hline Cuba & HIGH & 9000 & 43 & 43 & 67 & 17 & 2 & 67 & 47 & 61 & 122 & SUCCESSFUL & 84,8935 & 23 & 33 & 67 & 5 & 44 & 128 & 18 & 35 & 165 \\
\hline Cyprus & HIGH & 124 & 37 & 42 & 43 & 79 & 81 & 31 & 34 & 60 & 24 & SUC & 84,0308 & 36 & 117 & 43 & 72 & 61 & 17 & 101 & 11 & 101 \\
\hline Czech Rep. & \begin{tabular}{|l|} 
HIGH \\
\end{tabular} & 0,9098 & 40 & 53 & 12 & 59 & 3 & 10 & 99 & 17 & 72 & SUCCESSFUL & 84,3732 & 32 & 165 & 12 & 58 & 9 & 5 & 62 & 29 & 141 \\
\hline Denmark & \begin{tabular}{|l|} 
VERY 1 \\
\end{tabular} & 0,9549 & 6 & 18 & 84 & 11 & 24 & 7 & 10 & 26 & 20 & SUCC & 84,4484 & 31 & 148 & 83 & 12 & 52 & 106 & 138 & 8 & 11 \\
\hline Djibouti & VER & 0,6570 & 172 & 129 & 187 & 169 & 167 & 129 & 177 & 163 & 154 & FUL & 65,48141 & 182 & 99 & 187 & 169 & 167 & 113 & 127 & 145 & 187 \\
\hline Dominica & MEL & 8539 & 82 & 70 & 58 & 82 & 47 & 98 & 140 & 65 & 116 & SUCCESSFUI & 73,1573 & 146 & 185 & 58 & 79 & 147 & 96 & 82 & 160 & 95 \\
\hline Dominican R. & MEDIUM & 8400 & 98 & 124 & 122 & 62 & 128 & 118 & 103 & 29 & 79 & ESSFUL & 6913 & 113 & 45 & 122 & 65 & 124 & 130 & 57 & 119 & 155 \\
\hline Ecuador & HIGH & 8782 & 58 & 119 & 13 & 22 & 100 & 107 & 120 & 12 & 104 & UCCESSFUL & 79,5715 & 84 & 66 & 13 & 21 & 78 & 86 & 141 & 169 & 100 \\
\hline Egypt, Arab R & MEDIUM & 8160 & 113 & 92 & 99 & 176 & 97 & 116 & 111 & 75 & 78 & SUC & 80,8076 & 67 & 82 & 99 & 175 & 46 & 26 & 80 & 109 & 35 \\
\hline El Sal & MED & 537 & 83 & 105 & 72 & 80 & 84 & 104 & 75 & 93 & 92 & & 709 & 52 & 57 & 73 & 87 & 42 & 108 & 71 & 93 & 64 \\
\hline Equatorial G & LOW & 103 & 151 & 84 & 164 & 177 & 182 & 140 & 156 & 101 & 103 & PARTIALLY UNSUCCESSFUL & 70,2625 & 166 & 18 & 164 & 179 & 181 & 81 & 174 & 122 & 124 \\
\hline Eritrea & LOW & 0,6860 & 159 & 136 & 181 & 142 & 120 & 168 & 88 & 183 & 173 & PARTIALLY UNSUCCESSFUL & 71,2508 & 157 & 20 & 180 & 143 & 36 & 153 & 44 & 180 & 186 \\
\hline Estol & $\mathrm{H}$ & 保 & 35 & 39 & 49 & 42 & 33 & 30 & 117 & 32 & 17 & SUC & 41 & 53 & 176 & 50 & 41 & 39 & 1 & 175 & 49 & 54 \\
\hline Ethiop & VER & 539 & 177 & 180 & 172 & 100 & 165 & 181 & 147 & 169 & 183 & PAR & 74,4041 & 140 & 64 & 172 & 111 & 89 & 173 & 72 & 152 & 47 \\
\hline Fiji & MEDIU & 547 & 81 & 78 & 104 & 134 & 88 & 102 & 78 & 45 & 70 & PARTIA & 77,9319 & 109 & 51 & 103 & 133 & 148 & 138 & 131 & 23 & 87 \\
\hline Finlan & VERY HIGH & 9429 & 17 & 25 & 14 & 3 & 8 & 8 & 54 & 38 & 46 & VERY SUCCESSFUL & 86,79786 & 0 & 68 & 14 & 4 & 68 & 55 & 68 & 37 & 33 \\
\hline France & VERY HIGH & 9521 & 7 & 29 & 18 & 25 & 73 & 19 & 48 & 6 & 8 & VER & 86,97739 & 7 & 83 & 18 & 25 & 94 & 21 & 66 & 15 & 16 \\
\hline Gabon & LOW & 760 & 133 & 85 & 136 & 147 & 159 & 141 & 172 & 34 & 95 & CCESSFU & & 143 & 76 & 136 & 145 & 177 & 156 & 126 & 6 & 159 \\
\hline Gambi & $\mathrm{LO}$ & 044 & 152 & 103 & 171 & 179 & 145 & 167 & 149 & 90 & 159 & Y SUCCESSFUL & 74,1462 & 141 & 7 & 171 & 181 & 104 & 167 & 161 & 62 & 26 \\
\hline Georgia & MEDII & 3566 & 78 & 133 & 33 & 81 & 101 & 88 & 62 & 68 & 108 & SUCCE & 80,5490 & 71 & 171 & 33 & 78 & 125 & 104 & 87 & 41 & 24 \\
\hline Germany & VERY HIGH & 9663 & 2 & 14 & 21 & 14 & 15 & 17 & 33 & 5 & 7 & VER & 86,67996 & 11 & 104 & 21 & 17 & 88 & 13 & 67 & 51 & 7 \\
\hline Ghana & LOW & 754 & 138 & 143 & 147 & 144 & 148 & 145 & 83 & 123 & 105 & UCCESSFUL & 521 & 125 & 56 & 147 & 141 & 144 & 135 & 42 & 154 & 14 \\
\hline Gree & $\mathrm{HI}$ & 0 & 30 & 81 & 35 & 56 & 7 & 35 & 21 & 24 & 54 & SUC & 444 & 26 & 116 & 35 & 56 & 65 & 56 & 34 & 19 & 77 \\
\hline Grenada & HIGH & 861 & 53 & 96 & 157 & 15 & 83 & 59 & 9 & 57 & 53 & PARTI & 74,9074 & 137 & 186 & 155 & 20 & 136 & 54 & 21 & 82 & 122 \\
\hline Guatemali & MEDIUM & 0,7953 & 126 & 151 & 131 & 127 & 117 & 144 & 130 & 33 & 99 & PARTIALLY SUCCESSFUL & 74,4692 & 139 & 129 & 131 & 127 & 77 & 163 & 143 & 131 & 89 \\
\hline Guinea & LOW & & 168 & 102 & 166 & 185 & 179 & 178 & 146 & 107 & 152 & PAR & & 174 & 25 & 166 & 185 & 145 & 174 & 149 & 89 & 160 \\
\hline Guinea-E & VERY & 6554 & 173 & 115 & 161 & 178 & 181 & 180 & 161 & 121 & 165 & ESSFUL & 68,1546 & 176 & 32 & 161 & 177 & 174 & 182 & 180 & 97 & 112 \\
\hline Guyana & $\mathrm{M}$ & 0 & 125 & 117 & 135 & 60 & 108 & 143 & 108 & 143 & 128 & CCESSFUL & 73,3201 & 144 & 123 & 135 & 71 & 117 & 170 & 181 & 126 & 69 \\
\hline Haiti & LOW & 0,6667 & 169 & 155 & 170 & 97 & 174 & 174 & 127 & 184 & 162 & PARTIALLY UNSUCCESSFUL & 71,3255 & 156 & 53 & 170 & 93 & 146 & 179 & 83 & 181 & 83 \\
\hline Honduras & MEDIU & 0,8242 & 108 & 127 & 105 & 73 & 98 & 139 & 105 & 66 & 115 & PARTIALLY SUCCESSFUL & 79,1249 & 94 & 70 & 105 & 75 & 60 & 133 & 64 & 168 & 71 \\
\hline Hong Kong & $\mathrm{HIG}$ & & 26 & 15 & 61 & 68 & 104 & 13 & 66 & 2 & 47 & & & 33 & 78 & 61 & 63 & 1 & 25 & 50 & 138 & 53 \\
\hline Hungary & HIGH & & 52 & 73 & 66 & 91 & 10 & 72 & 31 & 31 & 121 & & 80,5522 & 70 & 184 & 66 & 85 & 4 & 116 & 8 & 3 & 137 \\
\hline Iceland & VERY HIGH & 0,9511 & 8 & 2 & 41 & 1 & 57 & 37 & 5 & 56 & 38 & SUCCESSFUL & 83,9400 & 39 & 71 & 41 & 6 & 59 & 31 & 121 & 48 & 140 \\
\hline India & LOW & 0,7379 & 142 & 167 & 121 & 163 & 149 & 136 & 110 & 137 & 120 & PARTIALLY SUCCESSFUL & 75,4616 & 133 & 65 & 121 & 167 & 128 & 53 & 86 & 121 & 153 \\
\hline Indonesia & MEDIUM & 0,8012 & 122 & 128 & 80 & 114 & 132 & 128 & 151 & 96 & 114 & PARTIALLY SUCCESSFUL & 77,9828 & 107 & 44 & 81 & 117 & 82 & 95 & 176 & 118 & 86 \\
\hline
\end{tabular}




\begin{tabular}{|c|c|c|c|c|c|c|c|c|c|c|c|c|c|c|c|c|c|c|c|c|c|c|}
\hline Iran & MEDIUM & 0,8499 & 87 & 112 & 2 & 173 & 69 & 38 & 25 & 128 & 64 & SUCCESSFUL & 81,3548 & 62 & 97 & 2 & 174 & 15 & 21 & 58 & 90 & 151 \\
\hline Iraq & LOW & 0,7430 & 140 & 135 & 162 & 168 & 151 & 108 & 68 & 176 & 82 & PARTIALLY UNSUCCESSFUL & 69,3996 & 172 & 142 & 162 & 171 & 184 & 122 & 104 & 92 & 163 \\
\hline Ireland & HIGH & 0,9319 & 25 & 31 & 3 & 58 & 50 & 2 & 37 & 55 & 12 & VERY SUCCESSFUL & 86,98737 & 5 & 91 & 3 & 54 & 83 & 22 & 75 & 2 & 17 \\
\hline Israel & HIGH & 9394 & 21 & 8 & 23 & 39 & 20 & 11 & 38 & 72 & 5 & SUCCESSFUL & 81,3866 & 60 & 111 & 23 & 40 & 28 & 11 & 150 & 77 & 171 \\
\hline Italy & VERY HIGH & 0,9413 & 19 & 46 & 38 & 24 & 66 & 34 & 8 & 14 & 58 & VERY SUCCESSFUL & 86,73831 & 10 & 150 & 38 & 28 & 63 & 23 & 36 & 18 & 31 \\
\hline Jamaica & MEDIUM & 3245 & 107 & 109 & 109 & 85 & 86 & 100 & 109 & 125 & 129 & PARTIALLY SUCCESSFUL & 74,9308 & 136 & 145 & 109 & 80 & 116 & 136 & 117 & 102 & 170 \\
\hline Japan & $\mathrm{HIGH}$ & 0,9246 & 28 & 26 & 7 & 117 & 5 & 39 & 29 & 36 & 27 & VERY SUCCESSFUL & 85,29019 & 19 & 108 & 7 & 109 & 81 & 29 & 9 & 64 & 29 \\
\hline Jordan & MEDIUM & 0,8371 & 100 & 93 & 98 & 153 & 76 & 73 & 56 & 133 & 90 & PARTIALLY SUCCESSFUL & 77,0028 & 121 & 86 & 98 & 152 & 96 & 66 & 54 & 175 & 74 \\
\hline Kazakhstan & MEDIUM & 0,8489 & 88 & 40 & 103 & 34 & 75 & 69 & 116 & 177 & 65 & SUCCESSFUL & 80,6885 & 68 & 59 & 102 & 35 & 27 & 64 & 166 & 87 & 115 \\
\hline Kenya & LOW & 5995 & 153 & 174 & 126 & 120 & 143 & 160 & 166 & 175 & 144 & PARTIALLY UNSUCCESSFUL & 70,2677 & 165 & 140 & 126 & 121 & 154 & 177 & 155 & 179 & 70 \\
\hline Kiribati & MEDIUM & 0,7834 & 129 & 32 & 88 & 106 & 137 & 115 & 142 & 122 & 186 & PARTIALLY SUCCESSFUL & 77,0699 & 120 & 175 & 88 & 106 & 141 & 63 & 111 & 91 & 56 \\
\hline Korea, Re & HIGH & 0,9169 & 32 & 24 & 32 & 101 & 1 & 6 & 26 & 76 & 43 & SUCCESSFUL & 84,5124 & 29 & 38 & 32 & 105 & 93 & 89 & 10 & 67 & 48 \\
\hline Kuwait & HIGH & 3744 & 61 & 35 & 60 & 140 & 38 & 28 & 12 & 161 & 36 & UCCESSFUL & 78,9976 & 96 & 47 & 60 & 138 & 138 & 109 & 24 & 137 & 84 \\
\hline Kyrgyz Rep & \begin{tabular}{|l} 
MEDIUM \\
\end{tabular} & 142 & 114 & 77 & 75 & 53 & 93 & 86 & 144 & 149 & 168 & SUCCESSFUL & 79,1007 & 95 & 50 & 75 & 60 & 23 & 94 & 183 & 113 & 103 \\
\hline Lao PDR & LOW & 0,7623 & 137 & 152 & 116 & 92 & 152 & 151 & 135 & 124 & 107 & PARTIALLY SUCCESSFUL & 78,2137 & 106 & 63 & 117 & 99 & 99 & 74 & 153 & 86 & 94 \\
\hline Latvia & HIGH & 0,9161 & 33 & 63 & 78 & 38 & 44 & 60 & 44 & 35 & 33 & SUCCESSFUL & 83,1767 & 48 & 125 & 78 & 39 & 71 & 62 & 124 & 7 & 68 \\
\hline Lebanon & MEDIU & 0,8516 & 84 & 64 & 44 & 167 & 110 & 44 & 39 & 131 & 57 & SU & 64 & 41 & 85 & 44 & 165 & 75 & 12 & 14 & 73 & 51 \\
\hline Lesotho & LOW & 643 & 170 & 163 & 152 & 32 & 172 & 154 & 185 & 178 & 153 & SFUL & 68,4852 & 175 & 149 & 152 & 34 & 183 & 169 & 171 & 162 & 150 \\
\hline Liberia & VERY LOW & 0,6050 & 183 & 185 & 185 & 161 & 160 & 183 & 133 & 172 & 170 & UCCESSFUL & 69,3486 & 173 & 146 & 185 & 160 & 80 & 181 & 97 & 127 & 116 \\
\hline Libya & MEDIUM & 0,8512 & 86 & 58 & 76 & 138 & 59 & 25 & 61 & 157 & 60 & PARTIALLY SUCCESSFUL & 78,9437 & 98 & 88 & 76 & 139 & 12 & 14 & 136 & 147 & 129 \\
\hline Liechtenste & HIGH & 973 & 46 & 1 & 139 & 111 & 39 & 58 & 164 & 1 & 1 & ESSFUL & 77,9161 & 110 & 94 & 139 & 115 & 18 & 18 & 118 & 141 & 169 \\
\hline Lithuania & HIGH & 062 & 41 & 67 & 85 & 35 & 62 & 42 & 76 & 43 & 32 & VER & 86,41899 & 14 & 96 & 85 & 37 & 53 & 7 & 60 & 12 & 88 \\
\hline Luxembou & VERY I & 480 & 12 & 19 & 117 & 46 & 12 & 21 & 2 & 19 & 4 & VERY SUCCESSFUL & 86,47468 & 12 & 72 & 116 & 47 & 29 & 139 & 40 & 17 & 1 \\
\hline Macedonia & HIGH & 0,8723 & 66 & 126 & 69 & 23 & 14 & 90 & 96 & 77 & 87 & SUCCESSFUL & 80,1250 & 76 & 180 & 69 & 26 & 21 & 82 & 33 & 36 & 177 \\
\hline $\mathrm{Mad}$ & LOW & 80 & 171 & 186 & 165 & 112 & 166 & 147 & 157 & 174 & 143 & $\overline{\text { CESSFUL }}$ & & 150 & 181 & 165 & 114 & 114 & 90 & 96 & 108 & 146 \\
\hline Malawi & $\mathrm{LOI}$ & 960 & 156 & 177 & 141 & 154 & 139 & 148 & 165 & 117 & 179 & SUCCESSFUL & 78,5191 & 104 & 40 & 141 & 159 & 56 & 91 & 98 & 146 & 50 \\
\hline Malay: & $\mathrm{H}$ & 864 & 50 & 89 & 30 & 108 & 56 & 47 & 77 & 51 & 50 & SUCC & 80,6393 & 69 & 98 & 30 & 108 & 115 & 16 & 133 & 116 & 49 \\
\hline Maldives & HIGH & 683 & 71 & 62 & 93 & 105 & 31 & 105 & 35 & 58 & 126 & VERY SUCCESSFUL & 86,97917 & 6 & 5 & 93 & 100 & 16 & 27 & 7 & 85 & 81 \\
\hline Mali & VER & 002 & 181 & 165 & 182 & 160 & 180 & 179 & 167 & 168 & 161 & CCESSFUL & & 152 & 92 & 182 & 156 & 163 & 176 & 156 & 83 & - \\
\hline Malta & HIGH & $\overline{99}$ & 44 & 37 & 90 & 99 & 54 & 14 & 41 & 116 & 3 & SUC & & 66 & 143 & 90 & 101 & 133 & 58 & 99 & 38 & 22 \\
\hline Maurita & Y LOV & 504 & 175 & 148 & 163 & 133 & 162 & 164 & 180 & 187 & 139 & CCESSFUL & 71,2455 & 158 & 6 & 163 & 136 & 164 & 171 & 168 & 187 & 12 \\
\hline Mauritius & HIGH & 0,8728 & 64 & 65 & 97 & 87 & 64 & 68 & 55 & 126 & 52 & PARTIALLY SUCCESSFUL & 76,9198 & 123 & 159 & 97 & 92 & 140 & 137 & 106 & 72 & 85 \\
\hline Mexico & HIGH & 0,8911 & 47 & 86 & 40 & 28 & 61 & 96 & 74 & 44 & 76 & SUCCE & 82,0171 & 56 & 154 & 40 & 32 & 19 & 103 & 49 & 43 & 154 \\
\hline Micro & & 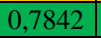 & 128 & 95 & 87 & 131 & 127 & 87 & 45 & 110 & 187 & & & 72 & 1 & 87 & 125 & 158 & 42 & 22 & 106 & 157 \\
\hline Moldov & $\mathrm{M}$ & ( & 105 & 101 & 96 & 44 & 96 & 76 & 136 & 134 & 147 & $\overline{F U L}$ & 120 & 111 & 158 & 96 & 42 & 122 & 117 & 184 & 1 & 91 \\
\hline Mongolia & MEDIUM & 0,8162 & 111 & 134 & 63 & 64 & 90 & 83 & 114 & 167 & 117 & SUCC & 84,0369 & 35 & 93 & 63 & 61 & 3 & 79 & 41 & 98 & 43 \\
\hline Montenegro & HIGH & 0,8887 & 48 & 94 & 92 & 66 & 70 & 51 & 46 & 40 & 71 & SUCCESSFUL & 81,1963 & 64 & 133 & 92 & 67 & 54 & 105 & 11 & 78 & 156 \\
\hline Morocco & \begin{tabular}{|l} 
MEDIUM \\
\end{tabular} & 0,7975 & 124 & 125 & 123 & 148 & 99 & 127 & 150 & 89 & 101 & SUC & & 77 & 121 & 123 & 150 & 51 & 70 & 119 & 56 & 36 \\
\hline Mozam & VERY LOW & 0,63 & 179 & 179 & 167 & 130 & 156 & 158 & 182 & 162 & 182 & PAR & & 160 & 48 & 167 & 132 & 70 & 154 & 162 & 185 & 125 \\
\hline Myanm & LOW & & 139 & 147 & 129 & 123 & 142 & 132 & 169 & 105 & 138 & PARTI & 79,7248 & 81 & 10 & 130 & 118 & 126 & 71 & 132 & 84 & 62 \\
\hline Namibia & MEDIUM & 0,7872 & 127 & 149 & 134 & 49 & 138 & 122 & 168 & 81 & 112 & PARTIALLY SUCCESSFUL & 75,9150 & 130 & 42 & 134 & 51 & 129 & 132 & 129 & 148 & 135 \\
\hline Nepal & LOW & 0,7365 & 143 & 120 & 156 & 145 & 130 & 170 & 107 & 115 & 151 & PARTIALLY SUCCESSFUL & 76,8031 & 124 & 23 & 157 & 158 & 57 & 142 & 63 & 105 & 119 \\
\hline Netherli & VERY HIGH & 0,9656 & 3 & 17 & 24 & 5 & 21 & 5 & 15 & 22 & 11 & VERY SUCCESSFUL & 85,97745 & 17 & 156 & 24 & 8 & 85 & 88 & 30 & 20 & 8 \\
\hline & $\mathrm{VE}$ & & 16 & 23 & 15 & 10 & 45 & 43 & 72 & 16 & 14 & & & 34 & 131 & 15 & 15 & 105 & 92 & 45 & 53 & 25 \\
\hline Nicaragua & MEDIUM & 0,8221 & 109 & 108 & 150 & 33 & 87 & 121 & 100 & 63 & 150 & PARTIALLY SUCCESSFUL & 79,5680 & 86 & 46 & 150 & 30 & 38 & 67 & 158 & 112 & 105 \\
\hline
\end{tabular}


Niger

\begin{tabular}{|l}
\hline Nigeria \\
\hline Norway \\
\hline
\end{tabular}

Norway

Oman

Pakistan

Palau

Panama

Papua New G.

\begin{tabular}{|l}
\hline Paraguay \\
\hline Peru
\end{tabular}

\begin{tabular}{|l} 
Peru \\
\hline Philippines \\
\hline Poling
\end{tabular}

\begin{tabular}{|l} 
Philippines \\
\hline Poland \\
\hline
\end{tabular}

\begin{tabular}{|l}
\hline Poland \\
\hline Portugal
\end{tabular}

\begin{tabular}{|l}
\hline Portugal \\
\hline Qatar \\
\hline Roman
\end{tabular}

\begin{tabular}{l}
\hline Qatar \\
\hline Romania \\
\hline
\end{tabular}

Romanian Fed.

Russian Fed

Rwanda

\begin{tabular}{l} 
Samoa \\
\hline Sao Tome \\
\hline
\end{tabular}

Saudi Arabia

Senegal

Serbia

\begin{tabular}{l} 
Seychelles \\
\hline Sia
\end{tabular}

\begin{tabular}{|l|}
\hline Sierra Leone \\
\hline
\end{tabular}

\begin{tabular}{l}
\hline Singapore \\
\hline Slovak \\
\hline
\end{tabular}

\begin{tabular}{l} 
Singapore \\
\hline Slovak Rep.
\end{tabular}

\begin{tabular}{l} 
Slovenia \\
\hline Solonon \\
\hline
\end{tabular}

Solomon Isl.

South Africa

\begin{tabular}{l} 
Spain \\
\hline
\end{tabular}

Spain

\begin{tabular}{|l} 
Sri Lanka \\
\hline St. Kitts and N. \\
\hline
\end{tabular}

St. Lucia

St. Vincent and

Sudan

\begin{tabular}{|l}
\hline Suriname \\
\hline Swaziland \\
\hline
\end{tabular}

\begin{tabular}{|l}
\hline Suriname \\
\hline Swaziland \\
\hline Sweden
\end{tabular}

\begin{tabular}{|l}
\hline Swaziland \\
\hline Sweden \\
\hline
\end{tabular}

\begin{tabular}{|l}
\hline Sweden \\
\hline Switzerland \\
\hline Syrian
\end{tabular}

\begin{tabular}{l}
\hline Switzerlan \\
\hline Syrian
\end{tabular}

Tajikistan

\begin{tabular}{|l}
\hline Tanzania \\
\hline Thailand
\end{tabular}

\begin{tabular}{|l}
\hline Thailand \\
\hline Timor-Leste \\
\hline Togo
\end{tabular}

\begin{tabular}{|l}
\hline Timor-Lest \\
\hline Togo
\end{tabular}

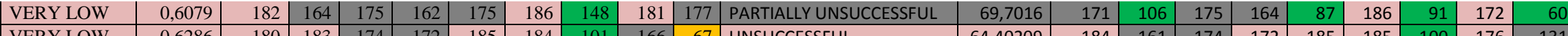

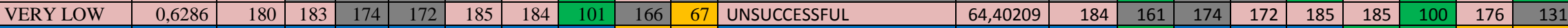

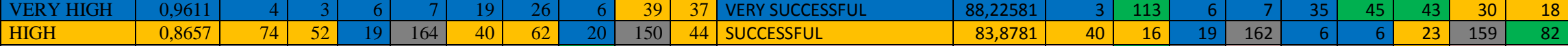

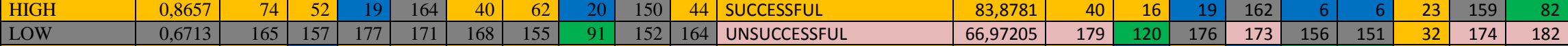

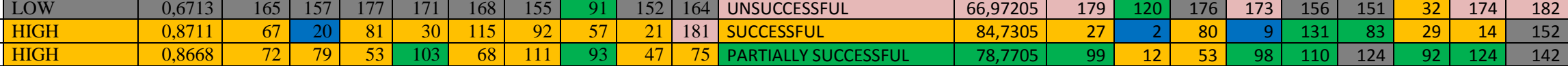

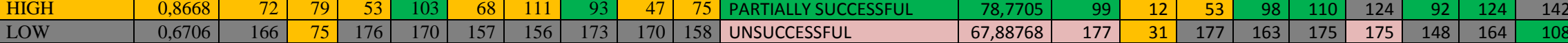

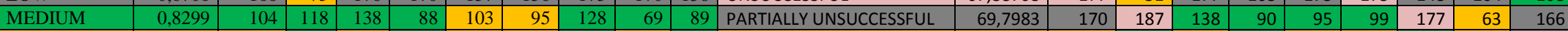

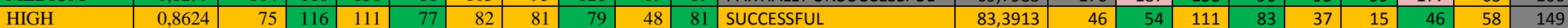

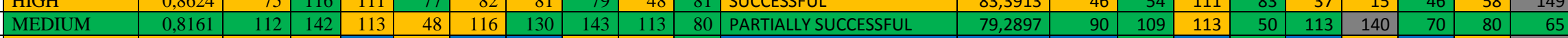

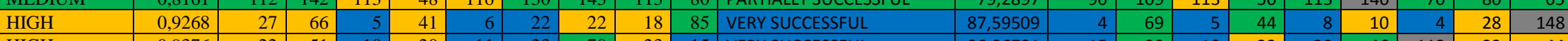

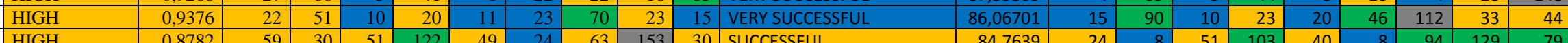

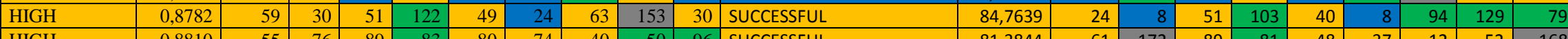

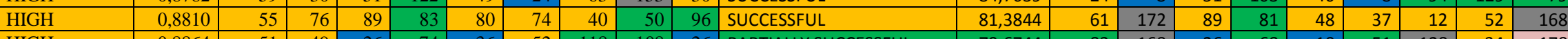

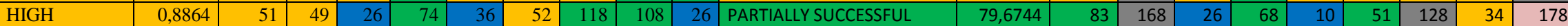

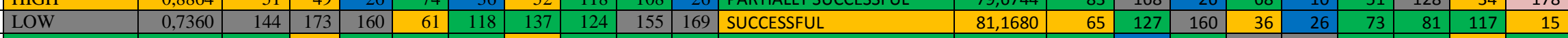

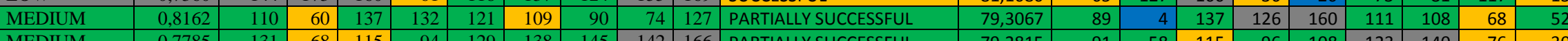

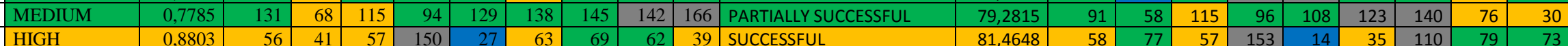

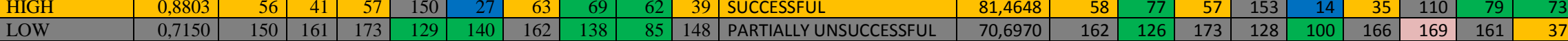

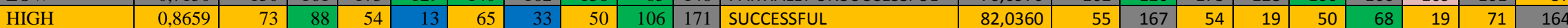
\begin{tabular}{|l|r|r|r|r|r|r|r|r|r|r|r|r|}
\hline MEDIUM & 0,8487 & 89 & 83 & 95 & 4 & 52 & 135 & 139 & 95 & 131 & PARTIALIY SUCCESSFUL \\
\hline
\end{tabular} \begin{tabular}{|l|r|r|r|r|r|r|r|r|r|r|r|r|r|}
\hline VERY LOW & 0,5841 & 185 & 159 & 179 & 175 & 186 & 176 & 181 & 164 & 163 & UNSUCCESSFUL \\
\hline
\end{tabular}

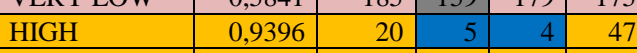
\begin{tabular}{|l|r|r|r|r|r|}
\hline HIGH & 0,9356 & 23 & 45 & 50 & 50 \\
\hline
\end{tabular}

\begin{tabular}{r|r|r|r|r|r|r|r|r|}
\hline 25 & 32 & 13 & 4 & 73 & SUCCESSFUL \\
\hline
\end{tabular}

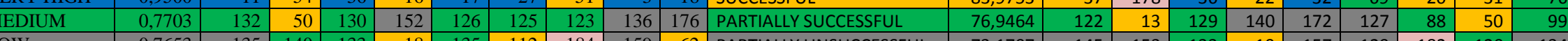

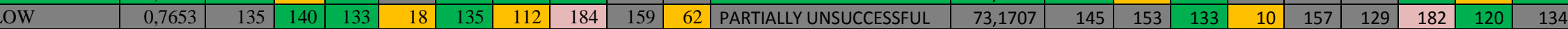

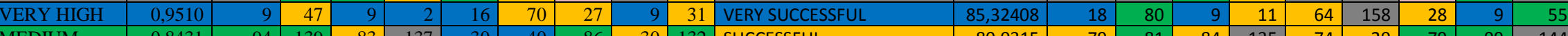

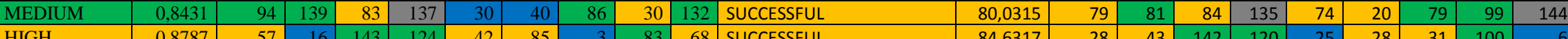

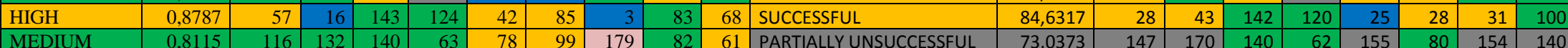

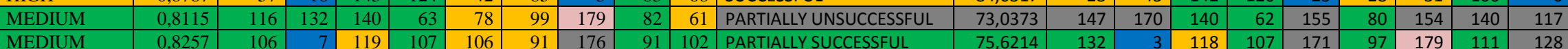

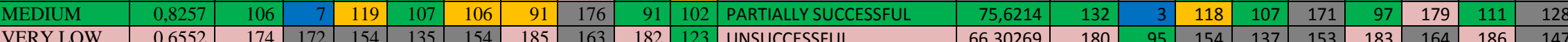
\begin{tabular}{|r|r|r|r|r|r|r|r|r|r|r|r|r|r|r|r|}
163 & 182 & 123 & UNSUCCESSFUL & 66,30269 & 180 & 95 & 154 & 137 & 153 & 183 & 164 & 186 & 147 \\
\hline 95 & 46 & 83 & SUCCESFUL & 80,0702 & 78 & 21 & 74 & 113 & 90 & 157 & 123 & 32 & 98 \\
\hline
\end{tabular}

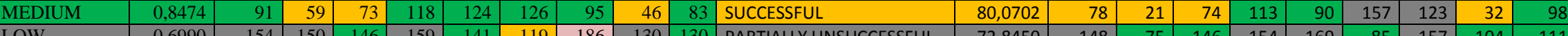

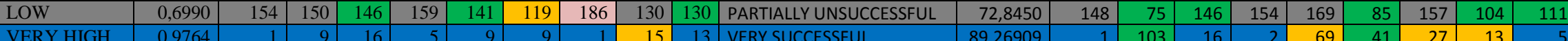

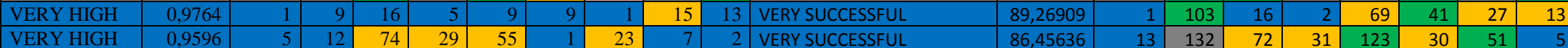

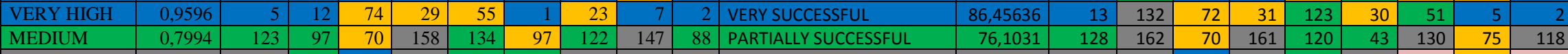

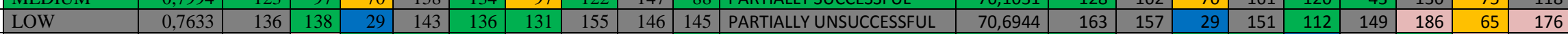

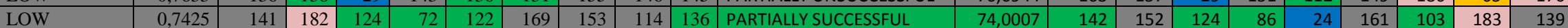

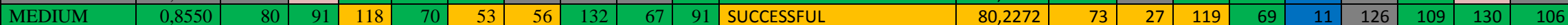

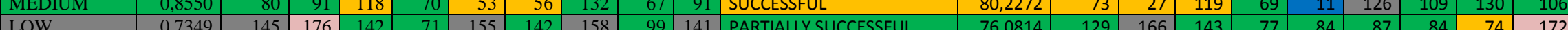

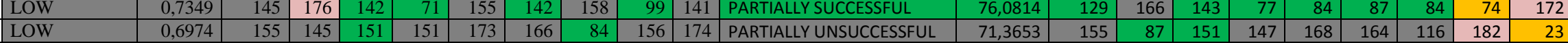




\begin{tabular}{|c|c|c|c|c|c|c|c|c|c|c|c|c|c|c|c|c|c|c|c|c|c|c|}
\hline Tonga & MEDIUM & 8026 & 121 & 162 & 48 & 139 & 58 & 101 & 36 & 102 & 175 & PARTIALLY SUCCESSFUL & 78,9453 & 97 & 164 & 49 & 134 & 106 & 145 & 5 & 59 & 96 \\
\hline Trinidad and & HIGH & 0,8699 & 69 & 44 & 46 & 26 & 109 & 114 & 59 & 165 & 35 & PARTIALLY SUCCESSFUL & 78,6211 & 102 & 55 & 46 & 27 & 143 & 112 & 147 & 125 & 80 \\
\hline Tunisia & MEDIUM & 0,8561 & 79 & 111 & 34 & 90 & 74 & 53 & 102 & 88 & 106 & SUCCESSFUL & 82,9205 & 49 & 135 & 34 & 102 & 30 & 24 & 137 & 24 & 92 \\
\hline Turkey & MEDIUM & 8419 & 97 & 100 & 37 & 141 & 51 & 94 & 60 & 109 & 110 & PARTIALLY SUCCESSFUL & 79,5005 & 88 & 160 & 37 & 146 & 13 & 40 & 25 & 107 & 161 \\
\hline Turkmeni & MEDIU & 8336 & 101 & 99 & 8 & 65 & 125 & 65 & 65 & 179 & 86 & Y SUCCESSFUL & 77,7098 & 112 & 62 & 8 & 66 & 111 & 101 & 61 & 150 & 174 \\
\hline Uganda & LOW & 0,6912 & 158 & 166 & 158 & 119 & 144 & 161 & 171 & 151 & 155 & PARTIALLY SUCCESSFUL & 74,8508 & 138 & 100 & 158 & 130 & 67 & 148 & 151 & 136 & 39 \\
\hline Ukraine & MEDIUM & 0,8378 & 99 & 57 & 45 & 86 & 112 & 61 & 126 & 148 & 113 & PARTIALLY SUCCESSFUL & 77,2922 & 119 & 107 & 45 & 82 & 130 & 50 & 167 & 4 & 184 \\
\hline United Arab E. & HIGH & 0,8764 & 60 & 33 & 114 & 128 & 60 & 64 & 32 & 119 & 28 & SUCCESSFUL & 80,1869 & 75 & 147 & 114 & 131 & 98 & 60 & 37 & 55 & 58 \\
\hline United Kingd. & VERY HIGH & 0,9458 & 14 & 27 & 17 & 45 & 34 & 45 & 16 & 27 & 16 & SUC & 862 & 47 & 114 & 17 & 46 & 92 & 131 & 122 & 27 & 4 \\
\hline United States & HIGH & 0,9336 & 24 & 21 & 52 & 57 & 67 & 29 & 11 & 42 & 29 & SUC & 82,1097 & 54 & 67 & 52 & 53 & 142 & 120 & 35 & 69 & 34 \\
\hline Uruguay & HIGH & 0,8986 & 45 & 69 & 25 & 78 & 35 & 54 & 30 & 80 & 59 & SUCCESSFUL & 83,5766 & 43 & 118 & 25 & 70 & 34 & 77 & 93 & 16 & 90 \\
\hline Uzbekistal & MEDIUM & 0,8320 & 102 & 122 & 64 & 104 & 114 & 49 & 129 & 120 & 93 & PARTIALLY SUCCESSFUL & 78,7272 & 101 & 137 & 64 & 112 & 97 & 34 & 89 & 45 & 173 \\
\hline Vanuatu & $\mathrm{ME}$ & 0,7813 & 130 & 123 & 107 & 157 & 147 & 120 & 52 & 97 & 160 & SFUL & 75,3935 & 134 & 29 & 107 & 148 & 176 & 115 & 26 & 101 & 175 \\
\hline Venezuela, RB & HIGH & 0,8727 & 65 & 82 & 71 & 76 & 95 & 110 & 115 & 37 & 45 & SUCCESSFUL & 76,5046 & 127 & 79 & 71 & 73 & 119 & 141 & 160 & 144 & 67 \\
\hline Vietnam & MEI & 8441 & 93 & 114 & 42 & 52 & 105 & 77 & 71 & 111 & 140 & SUC & 83,5831 & 42 & 15 & 42 & 55 & 102 & 36 & 102 & 110 & 45 \\
\hline West Bank & MEDIUM & 0,8313 & 103 & 137 & 102 & 109 & 102 & 48 & 19 & 140 & 137 & PARTIALLY SUCCESSFUL & 79,2047 & 93 & 84 & 101 & 89 & 165 & 9 & 55 & 143 & 109 \\
\hline Yemen, Rep. & LOW & 0,6796 & 161 & 160 & 145 & 187 & 164 & 152 & 73 & 185 & 98 & PARTIALLY UNSUCCESSFUL & 71,8530 & 151 & 163 & 145 & 186 & 150 & 76 & 39 & 151 & 93 \\
\hline Zambia & LOV & 0,6715 & 164 & 187 & 144 & 165 & 153 & 171 & 178 & 78 & 124 & PARTIALLY UNSUCCESSFUL & 70,2329 & 167 & 174 & 144 & 168 & 86 & 178 & 76 & 155 & 114 \\
\hline Zimbabwe & LOW & 0,7282 & 147 & 168 & 94 & 116 & 150 & 150 & 183 & 79 & 135 & PARTIALLY UNSUCCESSFUL & 69,9563 & 169 & 179 & 94 & 123 & 179 & 165 & 146 & 177 & 27 \\
\hline
\end{tabular}

MDGs index and MDGs success/performance level are created by considering 187 countries for the period of 1990-2015. Results of Sub-indexes for every indicators, targets and goals and General MDGs index and success/performance level created by using different average method (arithmetic, geometric and weighted) are also available. Countries' development and performance levels are determined by taking into consideration the results of each MDGs index and success rate in 2015.

*Development levels of the Countries are classified according to MDGs index value in five categories from "VERY HIGH" to "VERY LOW". Each color in the cells of table represents standard development levels where "VERY HIGH" countries are represented by blue color ... and "VERY LOW" countries are represented by pink color.

**Performance levels of the Countries are classified according to MDGs success rate in five categories from the "VERY SUCCESSFUL" to "UNSUCCESSFUL". Each color in the cells of table represents a standard performance levels where "VERY SUCCESSFUL" countries are represented by blue color ... and "UNSUCCESSFUL" countries are represented by pink color. 


\section{Appendix 4:}

$\checkmark$ Collecting the raw data for the indicators

○ World Bank database (World Development Indicators Online-CDROM and Book, Millennium Development Goals Online) (World Bank, 2012b, 2014a, 2014b, 2014c).

- Relevant International Organizations Online Data sets (see Appendix 6 Table)

$\checkmark$ Selection of Analysis Period and Countries

○ Base Year:1990 and Final Year:2015

○ 187 countries covered also by HDI

$\checkmark$ Completion of Missing Data and Prediction of the Value for Target Year (2015). Interpolation using Eviews 8 and SPSS 20 softwares. (Çilingirtürk and Altaş, 2010)

$\checkmark$ Deciding the averaging method:

Although indexes are calculated and compared by using all 3 average methods (arithmetic, geometric and weighted), weighted average method has considering its advantages on other methods.

$\checkmark$ Analysis of the produced indexes (Indexes for Indicators, Targets and Goals): 44 of 60 indicators, 19 of 21 targets and 8 of 8 goals are forecasted and analyzed. 16 indicators and 2 targets dropped from the analysis mainly due to lack of data availability.

$\checkmark$ Determination of the countries' development level and the MDGs Index Ranking by using index formula.

$\checkmark$ Determination of the country's MDG Achievement Levels and their Performance by using success formula. 


\section{Appendix 5:}

Index calculation if the higher values of the indicator indicates a better outcome:

$$
\text { Indeks } X_{\mathrm{IJt}}=\left(\mathrm{X}_{\mathrm{IJt}}-\mathrm{X}_{\mathrm{Min}}\right) /\left(\mathrm{X}_{\mathrm{Max}}-\mathrm{X}_{\mathrm{Min}}\right)
$$

Index calculation if the higher values of the indicator indicates a worse outcome:

$$
\text { Indeks } X_{\mathrm{ijt}}=\left(X_{\text {Max }}-X_{\mathrm{ijt}}\right) /\left(X_{\operatorname{Max}}-X_{\text {Min }}\right)
$$

Term in the Formula
Index $X_{\mathrm{ijt}}=$
$\mathrm{j}=1, \ldots \ldots .187$
$\mathrm{i}=1, \ldots \ldots .60$
$\mathrm{i}=1, \ldots \ldots \ldots .21$
$\mathrm{i}=1, \ldots \ldots \ldots .8$
$\mathrm{i}=1$
$\mathrm{t}=1990,1991, .2015$
$\mathrm{X}_{\operatorname{Min}}=$
$\mathrm{X}_{\mathrm{Max}}=$

\section{Term in the Formula}

\section{Meaning of the term}

index value of $j$. country for $i$. Indicator in $t$. year

\# of Countries

\# of Indicators

\# of Targets

\# of Goals

General Index of MDGs

Analysis period: 1990-2015

Min value of $i$. indicator in data set

Max value of i. indicator in target year of 2015 or in the data 


\section{Appendix 6: Other Data Sources Used for MDGs Analyses}

\begin{tabular}{|c|c|c|}
\hline GOALS & DATA SOURCES & RELATED WEB SITE \\
\hline \multirow{6}{*}{$\begin{array}{c}\text { MDG 1 } \\
\text { Eradicate extreme } \\
\text { poverty and hunger }\end{array}$} & World Bank, Development Research Group & http://iresearch.worldbank.org/PovcalNet/index.htm \\
\hline & $\begin{array}{l}\text { International Labor Organization (ILO), Labor } \\
\text { Market Database Basic Indicators }\end{array}$ & $\begin{array}{l}\text { http://www.ilo.org/global/statistics-and- } \\
\text { databases/lang--en/index.htm }\end{array}$ \\
\hline & $\begin{array}{l}\text { World Health Organization (WHO), Global } \\
\text { Database on Child Development and Malnutrition }\end{array}$ & http://www.who.int/nutgrowthdb/en/ \\
\hline & $\begin{array}{l}\text { EUROSTAT - Income, Social Exclusion and } \\
\text { Living Conditions Statistics }\end{array}$ & $\begin{array}{l}\text { https://ec.europa.eu/eurostat/web/income-and- } \\
\text { living-conditions/overview }\end{array}$ \\
\hline & UN MDGs Database & $\begin{array}{l}\text { https://millenniumindicators.un.org/unsd/mdg/Data. } \\
\text { aspx }\end{array}$ \\
\hline & $\begin{array}{l}\text { United Nations Food and Agriculture } \\
\text { Organization (FAO) }\end{array}$ & http://www.fao.org/faostat/en/\#data \\
\hline \multirow{3}{*}{$\begin{array}{c}\text { MDG 2 } \\
\text { Achieve Universal } \\
\text { Primary Education }\end{array}$} & $\begin{array}{l}\text { UN Educational, Scientific and Cultural } \\
\text { Organization (UNESCO) }\end{array}$ & $\begin{array}{l}\text { http://stats.uis.unesco.org/unesco/TableViewer/table } \\
\text { View.aspx?ReportId=210 }\end{array}$ \\
\hline & EUROSTAT - Education and Training Statistics & $\begin{array}{l}\text { https://ec.europa.eu/eurostat/web/education-and- } \\
\text { training }\end{array}$ \\
\hline & UN MDGs Database & $\begin{array}{l}\text { https://millenniumindicators.un.org/unsd/mdg/Data. } \\
\text { aspx }\end{array}$ \\
\hline \multirow{4}{*}{$\begin{array}{c}\text { MDG 3 } \\
\text { Promote Gender } \\
\text { Equality And } \\
\text { Empower Women }\end{array}$} & $\begin{array}{l}\text { UN Educational, Scientific and Cultural } \\
\text { Organization (UNESCO) }\end{array}$ & http://data.uis.unesco.org/?ReportId=211 \\
\hline & $\begin{array}{l}\text { International Labor Organization (ILO), Labor } \\
\text { Market Data Set Basic Indicators }\end{array}$ & $\begin{array}{l}\text { http://www.ilo.org/global/statistics-and- } \\
\text { databases/lang--en/index.htm }\end{array}$ \\
\hline & UN MDGs Database & $\begin{array}{l}\text { https://millenniumindicators.un.org/unsd/mdg/Data. } \\
\text { aspx }\end{array}$ \\
\hline & UN Women Indicator & http://www.ipu.org/wmn-e/world.htm \\
\hline \multirow{2}{*}{$\begin{array}{c}\text { MDG 4 } \\
\text { Reduce Child } \\
\text { Mortality }\end{array}$} & $\begin{array}{l}\text { UN Children's Fund (UNICEF) Statistics on } \\
\text { Monitoring the Status of Children and Women }\end{array}$ & http://www.childinfo.org/statistical_tables.html \\
\hline & World Health Organization (WHO) & http://www.who.int/gho/database/en/ \\
\hline $\begin{array}{c}\text { MDG 5 } \\
\text { Improve Maternal } \\
\text { Health }\end{array}$ & $\begin{array}{l}\text { UN Children's Fund (UNICEF) Data and } \\
\text { Statistics }\end{array}$ & https://www.unicef.org/sowc2017/1 \\
\hline \multirow{3}{*}{$\begin{array}{c}\text { MDG 6 } \\
\text { Combat HIV/AIDS, } \\
\text { Malaria, and Other } \\
\text { Diseases }\end{array}$} & $\begin{array}{l}\text { The Joint United Nations Programme on } \\
\text { HIV/AIDS (UNAIDS) Data Analysis }\end{array}$ & http://www.unaids.org/en/dataanalysis/ \\
\hline & UN MDGs Database & $\begin{array}{l}\text { https://millenniumindicators.un.org/unsd/mdg/Data. } \\
\text { aspx }\end{array}$ \\
\hline & $\begin{array}{l}\text { World Health Organization (WHO), Global } \\
\text { Health Observatory Data Warehouse }\end{array}$ & http://apps.who.int/gho/data/ \\
\hline \multirow{4}{*}{$\begin{array}{c}\text { MDG 7 } \\
\text { Ensure Environmental } \\
\text { Sustainability }\end{array}$} & UN MDGs Database & $\begin{array}{l}\text { https://millenniumindicators.un.org/unsd/mdg/Data. } \\
\text { aspx }\end{array}$ \\
\hline & $\begin{array}{l}\mathrm{CO} 2 \text { Information Analysis Center, Department of } \\
\text { Environmental Sciences }\end{array}$ & http://cdiac.ornl.gov/trends/emis/meth_reg.html \\
\hline & International Energy Agency (IEA Statistics) & https://www.iea.org/statistics/ \\
\hline & $\begin{array}{l}\text { United Nations Food and Agriculture } \\
\text { Organization (FAO), AQUASTAT Data }\end{array}$ & $\begin{array}{l}\text { http://www.fao.org/nr/water/aquastat/data/query/ind } \\
\text { ex.html }\end{array}$ \\
\hline \multirow{5}{*}{$\begin{array}{c}\text { MDG 8 } \\
\text { Develop a Global } \\
\text { Partnership for } \\
\text { Development }\end{array}$} & OECD Database & http://www.oecd.org/statistics/ \\
\hline & $\begin{array}{l}\text { OECD Official Development Assistance } \\
\text { Committee, Capital Flows to Developing } \\
\text { Countries }\end{array}$ & http://www.oecd.org/development/aidstatistics/ \\
\hline & $\begin{array}{l}\text { World Trade Organization (WTO), Global } \\
\text { Partnerships for Development }\end{array}$ & https://www.wto.org/english/res_e/res_e.htm \\
\hline & $\begin{array}{l}\text { International Telecommunication Union (ITU), } \\
\text { Information and Communication Development } \\
\text { Statistics }\end{array}$ & http://www.itu.int//TU-D/ict/index.html \\
\hline & UN MDGs Database & $\begin{array}{l}\text { https://millenniumindicators.un.org/unsd/mdg } \\
\text { aspx }\end{array}$ \\
\hline
\end{tabular}

